MICHAE BRULIŃSKI

UNIWERSYTET MUZYCZNY FRYDERYKA CHOPINA

\title{
WYBRANE POLSKIE PODRĘCZNIKI DO NAUKI GRY NA FORTEPIANIE Z I POŁOWY XIX WIEKU A PERSPEKTYWA SPOŁECZNEJ HISTORII MUZYKI
}

$W$ ielu aspektom fenomenu fortepianu w kulturze XIX w. poświęcono dotychczas znaczną liczbę opracowań. Ówczesne podręczniki i szkoły gry na instrumencie pozostają jednak poza głównym nurtem zainteresowań badaczy, szczególnie w Polsce. Jedynym względnie kompletnym opracowaniem dotyczącym polskich podręczników pianistycznych jest wciąż praca magisterska Elżbiety Osiak . Autorka co charakterystyczne dla podobnych, nielicznych publikacji - skoncentrowała uwagę przede wszystkim na zawartym w źródłach materiale muzycznym. Postanowiłem pójść o krok dalej i podjąć refleksję nad potencjalną możliwością wykorzystania polskich szkół gry w badaniach nad społeczną historią instrumentu sensu stricto i sensu largo, odsuwając na dalszy plan rozważania związane z rozwojem techniki pianistycznej oraz analizą dzieła muzycznego. Najważniejsze zatem były dla mnie narracyjne fragmenty podręczników. Rezultaty - chociaż skromne - są w moim odczuciu godne uwagi, ponieważ stanowić mogą przyczynek do szerszej analizy tego typu źródeł, szczególnie z pozycji komparatystycznych.

Fortepian jest z perspektywy społecznej przedmiotem niezwykle interesującym. Od początku swego istnienia stawał się medium autoprezentacji wielu osób w ramach publicznej i prywatnej wymiany; był eksponowany jako środek, za pomocą którego określona grupa komunikowała się z innymi, starając się demonstrować swój status. Fakt jego posiadania można było uznawać za jedno z wielu kryteriów dystynkcji społecznej. Gwałtowny wzrost popularności fortepianu na przełomie XVIII i XIX w. pociągnął za sobą zmianę społecznego statusu muzyka. Na „fortepianową

I Elżbieta Osiak, Polskie szkoty i podręczniki gry fortepianowej I80o-I9I4, Uniwersytet Warszawski I994 (praca magisterska). Trudno uznać za wyczerpujący pod jakimkolwiek kątem artykuł opublikowany w 1965 r. na łamach Ruchu Muzycznego: Hanna Harley, „Pierwsze najpopularniejsze polskie szkoły na fortepian", Ruch Muzyczny 9 (1965) nr 8, s. 8-9. 
modę” u progu XIX w. wpływ miało wiele czynników². Instrument ten zajmował uprzywilejowaną pozycję w romantycznym krajobrazie aksjologicznym. Miał liczne walory związane z życiem jednostki, a także w przestrzeniach społecznych. Kobiety wykorzystywały go jako narzędzie służące do podbudowywania poczucia swojej wartości intelektualnej i wzmocnienia atrakcyjności matrymonialnej, ze szczególnym uwzględnieniem szerokiego zestawu czynników emocjonalnych i ekspresyjnych towarzyszących wykonaniom³ ${ }^{3}$. Dla dzieci fortepian był towarzyszem rozmaitych gier i zabaw. Z męskiego punktu widzenia fortepian przydatny był przede wszystkim jako przedmiot służący demonstracji statusu, umożliwiający profesjonalną działalność muzyczną, szczególnie wirtuozowską oraz kompozytorską. Z relaksacyjnych i rozrywkowych walorów fortepianu korzystali wszyscy jego użytkownicy, bez względu na płeć. Mimo różnic dotyczących stopnia urbanizacji Królestwa Polskiego, dostrzec można wiele podobieństw w recepcji fenomenu fortepianu w Polsce i poza jej zachodnimi granicami. W życiu muzycznym Królestwa Polskiego fortepian odegrał szczególnie istotną rolę, nie tylko jako podstawowy instrument przeznaczony do salonowego muzykowania w różnych formach. Stanowił również medium służące kształtowaniu postaw patriotycznych i religijnych ${ }^{4}$.

Polskie szkolnictwo muzyczne I poł. XIX w. w perspektywie nauczania gry na fortepianie podzielić można na trzy obszary. Pierwszym z nich jest edukacja zinstytucjonalizowanas. W kilku kolejnych ustępach przedstawię zarys historii szkolnictwa muzycznego w Warszawie i Krakowie - dwóch najważniejszych ośrodkach instytucjonalnej edukacji muzycznej na ówczesnych ziemiach polskich; dwóch miastach, w których wydana została większość analizowanych przeze mnie w dalszej części eseju źródeł.

2 Niezwykle frapujący wątek dynamicznej ekspansji fortepianu w kulturze europejskiej przełomu XVIII i XIX w. podejmowało wielu badaczy z różnych dyscyplin naukowych. Socjologiczną perspektywę spojrzenia na ten fenomen otworzył Max Weber kanonicznym artykułem „Racjonalne i socjologiczne podstawy muzyki” (w oryg. „Die rationalen und soziologischen Grundlagen der Musik”), przekł. Marta Bucholc, Stan Rzeczy 3 (2013) nr I, s. II-26. Zainteresowanych odsyłam także do następujących pozycji: Michael Chanan, Musica Practica. The Social Practice of Western Music From Gregorian Chant to Posmodernism, London 1994, s. 195-218; Dietrich Hildebrant, Pianoforte: A Social History, London 1989; James Parakilas, Piano Roles. The Hundred Years of Life with the Pianos, New Haven 2002. Odnośnie do literatury polskojęzycznej nie można nie wspomnieć w tym miejscu publikacji prof. Beniamina Vogla, który historii fortepianu w Polsce poświęcił niemal cały swój dorobek naukowy, zob. m.in.: Beniamin Vogel, Fortepian polski, Warszawa 1995. Kulturowe wątki w pracach związanych z przemysłem fortepianowym podejmował również Krzysztof Rottermund (np. Budownictwo instrumentów muzycznych na terenie Wielkopolski w XIX i I. potowie XX wieku, Poznań 2002). Nad rolą fortepianu w kulturze XIX w. pochylała się także wielokrotnie Irena Poniatowska, np. w książce Muzyka fortepianowa i pianistyka w wieku XIX: aspekty artystyczne i spoteczne, Warszawa I99I.

3 Zob.: Arthur Loesser, Men, Women and the Pianos: A Social History, New York 20II; Lucy Green, Music Gender, Education, Cambridge 1997; Jeffrey Kallberg, Granice poznania Chopina, Warszawa 2013, s. 5I-84.

4 Zob.: Michał Bruliński, Szafa - zyrafa - radioodbiornik: o fenomenie fortepianu w kulturze polskiej przed powstaniem listopadowym, Uniwersytet Warszawski, Kolegium Artes Liberales, 2016 (praca magisterska).

5 O polskich placówkach edukacyjnych w tym okresie pisała m.in. Zofia Serbeńska, Warszawskie szkolnictwo muzyczne XIX wieku, Uniwersytet Warszawski 1954 (praca magisterska), oraz wspomniana Elżbieta Osiak (Polskie szkoty). 
Od I8ıo r. działała w Warszawie ${ }^{6}$ Szkoła Dramatyczna założona przez Wojciecha Bogusławskiego przy Teatrze Narodowym 7 . Z placówką nie współpracował jednak żaden pedagog wyspecjalizowany w nauce gry na klawikordzie lub fortepianie; jedynie Domenico Tonioli wykładał śpiew oraz teorię muzyki. Warto jednak zwrócić uwagę, że "teorią muzyki” nazywano ówcześnie naukę o zasadach muzyki skojarzoną w jeden przedmiot z kursem gry na fortepianie. Umiejętność gry na fortepianie miała służyć nie tyle edukacji przyszłego wirtuoza, ile raczej egzemplifikacji zadań teoretycznych oraz niezbędnemu procesowi umuzykalniania ucznia. Miejsce Tonioliego zajął już w I8I2 r. Karol Kurpiński ${ }^{8}$. W grudniu I8I4 r. stanowisko nauczyciela muzyki w Szkole Dramatycznej objął Józef Elsner. W zorganizowanym przez niego zespole pedagogicznym wciąż brakowało osobnego stanowiska dla nauczyciela gry na instrumencie?

W grudniu I8ı7 r. Szkoła Dramatyczna została przez Józefa Elsnera przeorganizowana i zmieniona w trzyletnią Szkołę Muzyki i Sztuki Dramatycznej, która w początkowym okresie działalności miała ok. 50 uczniów ${ }^{\text {10 }}$. To właśnie w drugiej z placówek pojawiły się regularne i dość liczne lekcje klawikordu" ${ }^{\mathrm{II}}$; warto nadmienić, że fortepian wykładał w niej od końca I8ı9 r. Alojzy Stople ${ }^{\mathrm{r} 2}$. Wspomnieć należy również o powstałej w I8I8 r. Szkole Publicznej Muzyki Elementarnej, która miała ok. 30 wychowanków. Po osiągnięciu porozumienia przez Komisję Rządową Spraw Wewnętrznych i Policji oraz Komisję Rządową Wyzwań i Oświecenia Publicznego, Elsner połączył ją w i82I r. ze Szkołą Muzyki i Sztuki Dramatycznej - w ramach Instytutu Muzyki i Deklamacji (który powstał jako część Oddziału Sztuk Pięknych pod auspicjami Wydziału Filozoficznego na Królewskim Uniwersytecie Warszawskim). Instytut stanowił pierwszą w historii polskiej dydaktyki pianistycznej szkołę muzyczną z prawdziwego zdarzenia, w której zajęć z fortepianu - w zależności od obranego kursu - bywało więcej niż zajęć z literatury. Stojący na jego czele Elsner wystarał się m.in. o zakup dwóch klawikordów z warszawskiej fabryki Leszczyńskiego, aby - dzięki dobrym instrumentom - zapewnić

6 Dzieje warszawskiego szkolnictwa muzycznego zostały wyczerpująco opisane przez Magdalenę Dziadek, której publikację wykorzystałem na potrzeby niniejszej rekonstrukcji. Zob.: Magdalena Dziadek, Od Szkoty Dramatycznej do Uniwersytetu. Dzieje wyższej uczelni muzycznej w Warszawie I8I0-20Io, t. I, Warszawa 20II. W warszawskim kontekście warto również przywołać starsze prace: Alicja Rutkowska, Dziatalność pedagogiczna Instytutu Muzycznego Warszawskiego (I860-19I7), Warszawa 1960, oraz tejże, Rola spoteczna Instytutu Muzycznego Warszawskiego i znaczenie jego dziatalności dla polskiej kultury muzycznej, Warszawa I980.

7 Oficjalne jej otwarcie odbyło się 4 VI I8II r. w Sali Redutowej warszawskiego Ratusza na Rynku Starego Miasta, por.: M. Dziadek, Od Szkoty Dramatycznej, s. 33.

8 Ibid., s. 36 .

9 Ibid., s. 40.

Io Ibid., s. 43 .

II Zależnie od roku: na pierwszym - 4 godz. tygodniowo w stosunku do 6 godz. śpiewu; na drugim - 6 godz. w stosunku do 8 godz. śpiewu; na trzecim -6 godz. w stosunku do 6 godz. śpiewu, por.: Z. Serbeńska, Warszawskie szkolnictwo, s. 22 i następne.

I2 M. Dziadek, Od Szkoty Dramatycznej, s. 46. 
efektywność kształcenia i wysoki poziom naukir ${ }^{13}$. Ponadto w Instytucie Muzyki i Deklamacji rozdzielono klasę klawikordu na niższą (kurs podstawowy), którą prowadził Piotr Wejnert, oraz wyższą, pod auspicjami Alojzego Stoplego. W I82I r. jako nauczyciel generałbasu i harmonii został dodatkowo zatrudniony znakomity „fortepianista” z Czech, Václav Vilém Würfel, zaś - jak ustaliła Magdalena Dziadek - do opieki nad dziewczętami zaangażowano Salomeę Paris, zawodową pianistkę i śpiewaczkę ${ }^{\mathrm{I}}$. Szkoła obfitowała zatem w dobrych instrumentalistów i pedagogów.

W związku z konfliktem Józefa Elsnera z Carlem Solivą, Instytut Muzyki i Deklamacji przeszedł jeszcze jedną reorganizację: placówka została w I826 r. podzielona na Szkołę Główną Muzyki przy Wydziale Nauk i Sztuk Pięknych Uniwersytetu Warszawskiego oraz Szkołę Dramatyczną i Śpiewu. W Szkole Głównej Muzyki klasę klawikordu prowadził Józef Jawurek, który współpracował również z Instytutem Rządowym Wychowania Panien.

Przez klasę kompozycji oraz przez kurs pianistyczny w Instytucie Muzyki i Deklamacji oraz Szkole Głównej Muzyki przewinęły się właściwie wszystkie kluczowe w polskim krajobrazie pianistycznym I poł. XIX w. postaci, jak m.in. Ignacy Feliks Dobrzyński, August Freyer, Julian Fontana, Józef Sikorski, Józef Stefani czy Józef Nowakowski. Na podstawie rozmaitych źródeł domniemywać można, że poziom edukacji pianistycznej w prowadzonych przez Elsnera placówkach był dość wysoki i z pewnością nie odstawał zbytnio od standardów większych miast niemieckich i francuskich. $Z$ pewną rezerwą należy jednak traktować wspomniane przez Magdalenę Dziadek polemiki w warszawskiej prasie, m.in. na łamach Tygodnika Muzycznego i Dramatycznego oraz Gazety Literackiej, w których zarzucano Elsnerowi zbytnie śrubowanie wirtuozowskiej klasy fortepianu ${ }^{\text {I5 }}$, bowiem społeczne oczekiwania i wyobrażenia dotyczące umiejętności gry na tym instrumencie ograniczone były w pierwszych trzech dziesięcioleciach do roli towarzyszącej, tj. prostych akompaniamentów do pieśni patriotycznych i religijnych, ewentualnie skromnych prezentacji salonowych. Ta sama autorka postawiła pytanie, czy pedagodzy opisanych szkół stanowili spójną grupę ${ }^{16}$, co wydaje się szczególnie interesujące w przypadku edukacji pianistycznej i położenia podwalin pod to, co określać można jako „polską szkołę pianistyczną”. Patrząc przez pryzmat podręczników do nauki gry na fortepianie (Dobrzyński, Sikorski, Nowakowski), wydaje się, że mimo wielu różnic dostrzec można pewne wspólne mianowniki, co postaram się wykazać w dalszej części artykułu.

Po powstaniu listopadowym żadna ze szkół nie została reaktywowana. Pierwsze inicjatywy związane z reorganizacją placówki szkolnictwa muzycznego wyłoniły się w kręgu Teatru Narodowego, który potrzebował śpiewaków i instrumentalistów. W I854 r. 
zaczęto rozważać możliwość otwarcia szkoły muzycznej i - „celem zapobieżenia wydalaniu się młodzieży za granicę dla kształcenia się w muzyce” - zawiązano komitet organizacyjny z Ignacym Feliksem Dobrzyńskim, Józefem Sikorskim, Ignacym Krzyżanowskim, Augustem Freyerem i Apolinarym Kątskim ${ }^{17}$. Dopiero jednak w I86I r. Kątskiemu udało się inaugurować Instytut Muzyczny, w którym znaczną uwagę przywiązywano nie tylko do kształcenia wirtuozowskiego, lecz również teoretycznego ${ }^{\mathrm{I} 8}$.

O ile w Warszawie zaobserwować można stałą obecność klasy fortepianu w niemal wszystkich instytucjach odpowiedzialnych za edukację muzyczną od końca drugiej dekady XIX w., o tyle w Krakowie ${ }^{\text {I9 }}$ klasa fortepianu zaczęła funkcjonować bardzo wcześnie, bowiem już w prywatnej szkole muzycznej Wacława Sierakowskiego przy ul. Grodzkiej $(\mathrm{I} 78 \mathrm{I}-87)^{20}$, jednak w późniejszych latach dostrzec możemy pewne luki w systemie instytucjonalnego kształcenia pianistycznego, aż do czasów szkoły założonej przez w I838 r. przez Franciszka Mireckiego. Początki krakowskiego szkolnictwa muzycznego związane były $\mathrm{z}$ nauczaniem w bursach ${ }^{21}$, organizowanych głównie przy kościołach, które dopiero z czasem zaczęły ustępować miejsca szkołom świeckim²2. Bursiści pobierali jedynie lekcje śpiewu, gry na organach, instrumentach smyczkowych i dętych; autorzy wspomnianych opracowań nie dotarli do dokumentów, które poświadczałyby istnienie klasy fortepianu w którejkolwiek z wymienionych placówek. Zarówno organy, jak instrumenty smyczko-

I7 Ibid., s. 74, cyt. za: J. Kleczyński, „O konserwatoriach muzycznych”, Echo Muzyczne, Teatralne i Artystyczne I (I885) nr 84, s. 284 .

I8 Więcej informacji o Instytucie Muzycznym znaleźć można w cytowanej publikacji Magdaleny Dziadek oraz w artykule: Alicja Rutkowska, „Nauczanie muzyki w Warszawie w II połowie XIX wieku”, w: Kultura muzyczna Warszawy II potowy XIX wieku, red. Andrzej Spóz, Warszawa 1980, s. 34-4I.

I9 W kontekście krakowskiego szkolnictwa publicznego przywołać należy dwie najważniejsze publikacje: Tadeusz Przybylski, Z dziejów nauczania muzyki w Krakowie od średniowiecza do czasów wspótczesnych, Kraków 1994; Jolanta Wąsacz-Krztoń, Ludzie i muzyka w Krakowie w I potowie XIX wieku, Rzeszów 2009. W niniejszej pracy nie przedstawiam streszczenia historii lwowskiego szkolnictwa muzycznego, odsyłając czytelników do rzetelnych publikacji Leszka Mazepy „Szkolnictwo muzyczne Lwowa w okresie austriackim (I772-I9I8)”, Musica Galiciana I (1997), s. 8I-IO2; Leszek Mazepa, Teresa Mazepa, Šlâh do Muzičnoï Akademiï u L'vovi: u dvoh tomah, t. I, Vid dobi mis'kih muzikantiv do Konservatorï, Lviv 2003. Powodem pominięcia Lwowa w toku mojego wywodu jest brak regularnej klasy fortepianu w ramach instytucji edukacyjnej we Lwowie aż do I854 roku. Według ustaleń autora, o tejże można mówić dopiero w odniesieniu do szkoły muzycznej przy Galicyjskim Towarzystwie Muzycznym, inaugurowanym w I854 r., które oficjalny status konserwatorium uzyskało dopiero w i88o roku. Klasę fortepianu prowadził tam uczeń Chopina, Karol Mikuli, w 1. I859-87. Z czasem dołączył do niego Ludwik Marek, zob.: L. Mazepa, „Szkolnictwo muzyczne”, s. 88.

20 T. Przybylski, $Z$ dziejów nauczania, s. 43. Najbardziej aktualny stan badań nad postacią Wacława Sierakowskiego przedstawił Michał Piekarski, „Ks. Wacław Sierakowski - propagator wiedzy o muzyce i organizator szkolnictwa muzycznego w okresie działalności Komisji Edukacji Narodowej”, Biuletyn Historii Wychowania 34 (2016), s. 85-99. Jolanta Wąsacz-Krztoń wspomina również o szkole Józefa Zygmuntowskiego, o której zachowały się jedynie nieliczne informacje, w których brak danych dotyczących klasy fortepianu lub klawikordu oraz np. ogólnej liczby uczniów i absolwentów.

2I Jak np. Bursa Muzyczna pod zarządem Towarzystwa Przyjaciół Muzyki (I8I8-38), zob.: T. Przybylski, $Z$ dziejów nauczania muzyki, s. 36. Powołanie do życia publicznej szkoły muzycznej było jednym z głównych statutowych celów Towarzystwa.

22 J. Wąsacz-Krztoń, Ludzie i muzyka, s. 5I. 
we i dęte są w kontekście muzyki sakralnej znacznie bardziej użyteczne niż fortepian, dlatego brak nauki gry na tym instrumencie w programie kształcenia nie powinien specjalnie dziwić, póki nie weźmiemy pod uwagę niewątpliwego zapotrzebowania społecznego.

W I838 r. do Krakowa przybył Franciszek Mirecki, uczeń Hummla i Cherubiniego, gruntownie wykształcony muzyk, który zajmował się nauczaniem śpiewu, kompozycji i fortepianu ${ }^{23}$. To właśnie Mirecki podjął trud zorganizowania szkoły podług zagranicznych wzorów, otwierając placówkę w swoim prywatnym mieszkaniu, gdzie - mimo trudnych warunków lokalowych - kształciło się około sześćdziesięciu uczniów i uczennic. W pierwszych latach istnienia szkoła nastawiona była na „priorytet wokalny”, co wydaje się naturalne z uwagi na szczególne zamiłowanie Mireckiego do opery²4. W I84I r. pozostałości po Bursie św. Anny włączone zostały do prowadzonej przezeń Szkoły Śpiewu, pierwszej placówki pod nadzorem rządowej władzy edukacyjnej, uformowanej przy Instytucie Technicznym. Szkoła podzielona została na Wydział Śpiewu oraz Wydział Instrumentalny. Mimo iż priorytety instytucji w dalszym ciągu związane były z muzyką kościelną i operową, od początku w jej strukturze funkcjonowała klasa fortepianu Wincentego Gorączkiewicza ${ }^{25}$, co wzmogło dynamikę kształcenia na kursie instrumentalnym ${ }^{26}$. Na kierunku instrumentalnym kształcili się wyłącznie mężczyźni. Nauka trwała trzy lata i, śladem krakowskiej tradycji, dostosowana była do potrzeb muzyki kościelnej; z całą pewnością nie była nastawiona - w odróżnieniu od klas fortepianu wyższego w szkołach warszawskich - na kształcenie wirtuozowskie. Fortepianu w szkole Mireckiego uczył w późniejszych latach Czech, Josef Blaschke oraz syn Franciszka - Stanisław Mirecki. Blaschke nadał Wydziałowi Instrumentalnemu Szkoły silnie pianistyczny profil poprzez likwidację nauki harmonii, gry na organach i instrumentach dętych oraz zwiększenie liczby godzin dydaktyki pianistycznej ${ }^{27}$. Szkoła Śpiewu przy Instytucie Technicznym zlikwidowana została dopiero w I873 roku.

Z kolei w roku 1848 założona została przez Antoniego Sokulskiego prywatna szkoła fortepianu ${ }^{28}$, której celem miało być „nowoczesne kształcenie muzyczne”. Założyciel placówki z dumą perorował na łamach prasy, twierdząc, że uczniowie jego szkoły „daw-

23 T. Przybylski, $Z$ dziejów nauczania muzyki, s. 37. Por.: Kazimierz Nowacki, „Listy Franciszka Mireckiego", Rocznik Krakowski 40 (1970), s. 68.

24 Na które z pewnością wpłynął ponad dwudziestoletni pobyt Mireckiego we Włoszech, por.: T. Przybylski, $Z$ dziejów nauczania muzyki, s. I40.

25 Który notabene był znakomitym organistą, zob.: ibid., s. 145 i nast.

26 Jak ustalił Tadeusz Przybylski, w klasie fortepianu Gorączkiewicza korzystano przede wszystkim z literatury zagranicznej: grywano etiudy Betiniego i Cramera, sonaty Beethovena, cykl Gradus ad Parnassum Clementiego oraz liczne transkrypcje symfonii na cztery ręce. Ogólnie w instytucji korzystano ze szkół skrzypcowych Spohra i Campagnolego oraz Baillota, w przypadku instrumentów dętych z Allgemeine Musikschule für Militär-Musik Nemetza, zob.: ibid., s. 42. Nie pojawia się w tej enumeracji żaden podręcznik do gry na fortepianie, jednak domyślać się można, że używano przede wszystkim z publikacji zagranicznych, autorstwa np. wspomnianego Bertiniego czy Hummla, u którego przecież kształcił się Mirecki.

27 Ibid., s. 45 .

28 Nazywa ją tak sam autor, co przeoczyli cytowani autorzy opracowań, pisząc o „szkole muzycznej”. 
niej ćwiczący z przymusu, teraz zasiadają do fortepianu w każdej wolnej chwili”29. Interesujące pozostają jego motywacje: pomoc - po licznych prośbach - „mniej zamożnej klasie”. Sokulski, po „rozeznaniu gruntu” w Pradze, Dessau i Paryżu, postanowił „badawczym okiem wyjąć co lepsze i co gorsze, stosując się do miejsca i okoliczności”3o. Przedstawiony na kolejnej stronie jego artykułu bilans finansowy szkoły, w którym wspomniany jest m.in. zakup fortepianów za kwotę 3,80o złp., świadczy o poważnym podejściu organizatora do tego przedsięwzięcia ${ }^{31}$. Artykuł Sokulskiego stanowi również świadectwo licznych napięć występujących między rozmaitymi placówkami muzycznymi i prywatnymi nauczycielami, które zaobserwować można również w Warszawie. Interesującym wątkiem aksjologicznym, który odróżnia krakowskie instytucje edukacji pianistycznej od Warszawy, jest nacisk na „nowoczesność” metod dydaktycznych, który dostrzec można w narracjach Mireckiego i Sokulskiego. Być może związany jest on z poczuciem peryferyjności krakowskich instytucji muzycznych, które mogło doskwierać obu organizatorom po powrocie z licznych europejskich wojaży, jednak hipoteza ta wymaga rozwinięcia w dalszych badaniach.

W rekonstrukcji krakowskiego szkolnictwa muzycznego wymienić należy również powstałą w I867 r. Szkołę Muzyczną Towarzystwa „Muza”, od I876 r. Towarzystwa Muzycznego w Krakowie (od I88I r. pod auspicjami Władysława Żeleńskiego), która w I888 r. uzyskała status konserwatorium.

Wraz ze wzrostem znaczenia salonu jako centrum życia rodzinnego, edukacja muzyczna stawała się na ziemiach polskich coraz bardziej ważką kwestią. Nieliczne szkoły muzyczne, które zazwyczaj borykały się z problemami finansowymi, nie wystarczały, aby zaspokoić głód umiejętności gry na fortepianie społeczności większych polskich miast, szczególnie Warszawy. W nabyciu tej niezbędnej dla dobrze urodzonych kobiet i przydatnej dla mężczyzn umiejętności pomagał cały sztab metrów gry na fortepianie. W I827 r. w stolicy oferowało swe usługi 26 metrów, w I829 r. było ich już $37^{32}$. Rzeczywista liczba prywatnych nauczycieli fortepianu była jednak kilkuna-

Zob.: Antoni Sokulski, „List o szkole muzycznej w Krakowie”, Czas 2 (I849) nr 4I, s. I.

Ibid.

Ibid., s. 2.

Przewodnik Warszawski I827, Warszawa I827, cz. 2, s. 24 oraz Przewodnik Warszawski I829, Warszawa I829, cz. 2, s. 26-27. Wskazane w Przewodnikach postaci to m.in.: Aubert, Barankiewicz, Bylewski, Brzozowicz, Józef Brzowski (I805-88, kompozytor, wiolonczelista, dyrygent i pedagog, prowadził w Instytucie Muzycznym klasę fortepianu dla wokalistów), Michał Czechowicz (kompozytor utworów tanecznych zamieszkały w Warszawie), Ignacy Feliks Dobrzyński (jego postać opisana w dalszym fragmencie pracy), Maksymilian Einert (zm. I850, kompozytor muzyki fortepianowej), Maurycy Ernemann (1800-66, pianista i kompozytor), Głębocki, Hermann (najpewniej Adam, I80o-75, wiolonczelista i później nauczyciel fortepianu „dodatkowego” w Konserwatorium), Hoffmann, Joachim Kaczkowski (I789-I829, skrzypek i kompozytor), bracia Kędzierscy, Koman (nie mógł być to Henryk, urodzony w I824 r. pianista, bowiem w I829 r. miałby zaledwie pięć lat; żaden z odnotowanych w słownikach posiadaczy tego nazwiska nie wpasowuje się w kryteria chronologiczne), Krall (najpewniej: Antoni, warszawski fabrykant fortepianów), Kratzer (najpewniej Andrzej, zm. I872, autor wielu miniatur fortepianowych), Lanckoroński, Ledworowski, Heinrich Lentz (I764-1839, dyrygent, pianista i kompozytor), Lissowski, Modliński, Murawski, Novi, 
stokrotnie wyższa, niż sugerują przewodniki, ponieważ renomowani nauczyciele nie musieli zabiegać o uczniów w prasie. Gry na fortepianie potrafiła nauczać niemal każda guwernantka, a mnóstwo prywatnych edukatorów zajmowało się muzyką hobbystycznie, na uboczu swoich zawodowych zainteresowań, nie ogłaszając publicznie swoich usług. Poziom metrów był zróżnicowany - od studentów i wykładowców Konserwatorium, jak Dobrzyński czy Ernemann ${ }^{33}$, aż po osoby, które w ogóle nie potrafiły grać na fortepianie (sic!). Dopiero w II poł. XIX w. wprowadzono świadectwa kwalifikacyjne dla nauczycieli prywatnych, wydawane przez Instytut Muzyczny po zaliczeniu egzaminów (tzw. „świadectwo talentu”). Poziom metrów amatorów stanowił powód utrapienia profesjonalistów, o czym świadczą liczne ustępy w prasie przełomu lat pięćdziesiątych i sześćdziesiątych ${ }^{34}$.

Pawłowski (najpewniej Jakub, kompozytor), Jan Peszke (I778-I830, warszawski pianista, dyrygent, nauczyciel, prezes Towarzystwa Amatorskiego Muzycznego), Richter, Sikierewski, Stefani (najpewniej Józef, I80o-76, kompozytor, skrzypek i dyrygent, syn Jana), Józef Szabliński (I808-72, wiolonczelista i waltornista, nauczyciel gry na dętych blaszanych związany z Instytutem Muzycznym), Szmidt, Wagner (nieznanego pochodzenia ociemniały pianista, który związany był z Warszawą, I780-I85o lub - co bardziej prawdopodobne - Józef, 1768-1855, nadworny wiolonczelista Stanisława Augusta Poniatowskiego oraz nauczyciel wiolonczeli i kontrabasu w Konserwatorium), Zawadzki (najpewniej Józef, I78I-I838, drukarz muzyczny działający w Warszawie). W przewodnikach podane są same nazwiska; imiona, daty urodzenia i śmierci oraz krótki opis postaci zrekonstruowałem na podstawie Stownika muzyków polskich (red. Józef Chomiński, t. I-2, Warszawa 1964, 1967) oraz Stownika muzyków polskich dawnych i nowoczesnych (red. Albert Sowiński, Paryż I874). Postaci, których imię nie zostało wskazane, nie figurują w żadnym ze wskazanych słowników, w Encyklopedii Muzycznej PWM, katalogu Biblioteki Narodowej, Polskim Stowniku Biograficznym, ani w żadnym z przebadanych przeze mnie źródeł. Z analizy przeprowadzonej przez Barbarę Chmarę-Żaczkiewicz, do powyższej listy metrów fortepianu należy również dopisać co najmniej kilku muzyków francuskich, niemieckich czy czeskich, jak Josef Jawurek, Antoni i Piotr Weinert, Wojciech Żywny czy Václav Vilém Würfel, zob.: Barbara Chmara-Żaczkiewicz, Václav Vilém Würfel w Warszawie i w Wiedniu. Fakty i hipotezy, Warszawa 20I7, s. 23. Z kolei Jolanta Wąsacz-Krztoń w swojej publikacji poświęconej krakowskiemu szkolnictwu muzycznemu również zauważyła, że od czasu zajęcia miasta przez Austriaków przez miasto przewinęło się - co wydaje się zupełnie naturalne - mnóstwo prywatnych nauczycieli fortepianu i klawikordu, m.in. z Brna, Pragi oraz Wiednia, zob.: J. Wąsacz-Krztoń, Ludzie i muzyka, s. 52 .

33 Ignacy Feliks Dobrzyński reklamował swoje usługi w prasie codziennej: „Artysta muzyczny, który miał szczęście łaskawie być przyjętym od prześwietnej publiczności, wykonując niedawno koncert w Teatrze Narodowym, przedsięwziąwszy mieszkać ciągle w tutejszej stolicy, oświadcza niniejszym, że osoby życzące brać u niego lekcje fortepianu, raczą się zgłosić u niego od godz. 7-9 rano, w Hotelu Polskim przy ulicy Długiej", zob.: Kurier Warszawski 7 (I827) nr 279 z I7 X. Większość metrów organizowała zajęcia w systemie kojarzonym później z rosyjskimi konserwatoriami: profesor gromadził uczniów z samego rana i nawet przez dwanaście godzin prowadził indywidualne zajęcia mistrzowskie, którym przysłuchiwali się wszyscy zebrani.

34 „Gdyby muzyka miała swoje zwierzchnictwo patentujące metrów, o wieleż by się rozświetliło na jej horyzoncie... wszakże wybierając mentora w jakim bądź innym zawodzie kołatamy do ludzi fachowych, zasięgamy rady, radę sprawdzamy... dla muzyki to zachód zbyteczny. Pan J. chociaż gra tylko na oboju w orkiestrze, tem samem potrafi uczyć na fortepianie, Pan L. bębni na kociołkach, też i uczniów pokieruje na klawiszowych doboszów, Pan S. na niczem nie gra, czyż za tem idzie, że nie nauczy? Pan $\mathrm{X}$ służy w kancelarii, w akcyzie, potem gizelował, ale mu jakoś nie wiodło się, więc nuż do chleba muzycznego, za to taniej daje lekcje”, cyt. za: Z. Serbeńska, Warszawskie szkolnictwo muzyczne, s. 23. 
Nauka gry na fortepianie rozpoczynała się zazwyczaj wcześnie, bowiem już około siódmego roku życia. Już po kilku lekcjach możliwe było opanowanie najogólniejszych podstaw gry i wykonanie prostej melodii, co zachęcało do dalszej nauki. Nadmienić należy, że większości adeptów sztuki pianistycznej wystarczała jedynie powierzchowna umiejętność gry i czytania nut ${ }^{35}$, co w kontekście społecznych oczekiwań pierwszych trzech dekad XIX w. wydaje się zupełnie zrozumiałe. Wielu rodziców dopingowało jednak swoje dzieci, aby szły w ślady Antosia Kątskiego czy Józia Krogulskiego, za którymi szalała warszawska publiczność ${ }^{36}$. O rozwój umiejętności muzycznych swoich dzieci dbali niemal wszyscy arystokraci i większość mieszczan. Nauka przebiegała jednak w trybie „niezbyt zintensyfikowanym”. Z pamiętnika Zofii z Czartoryskich Zamoyskiej dowiadujemy się, że kulminacyjny okres pianistycznej edukacji młodych panien przypadał najczęściej na piętnasty rok życia. Co ciekawe, nauka przerywana była zazwyczaj z momentem zamążpójścia młodej damy: „gdy pójdą za mąż, rzadko jest, żeby się która jeszcze nim [fortepianem - M.B.] trudniła, zarzucają go zupełnie, z nieodżałowaną stratą i nakładów czynionych, i z uszczerbkiem przyjemności, którą by sobie i innym przynosić mogły"37. Wyniesione z lekcji umiejętności oraz pamięć fortepianu jako przedmiotu pozostawały jednak w mentalności kobiet przez długie lata, czego dowód mogą stanowić wspomnienia Henriety z Działyńskich Błędowskiej, która spisując swój pamiętnik w wieku ponad sześćdziesięciu lat, wciąż pamiętała szczegóły dotyczące swoich dziecięcych lekcji ${ }^{8}$.

Trudno oszacować dokładnie liczbę osób, które na ziemiach polskich posiadły w I poł. XIX w. tajniki gry na fortepianie dzięki wsparciu instytucji muzycznych oraz dzięki usługom metrów. Śmiało można jednak założyć, że większości osób, które pragnęły kształcić pianistycznie siebie lub swoje dzieci, nie było stać na w pełni „profesjonalną” edukację muzyczną. To właśnie z myślą o tej grupie powstawały pierwsze podręczniki do nauki gry na instrumentach.

W 1. I8oo-30 nastąpił zasadniczy zwrot w rozwoju muzycznego ruchu wydawniczego w Warszawie ${ }^{39}$, ówczesnym muzycznym sercu Polski. Na terenie stolicy Królestwa Kongresowego działały trzy większe drukarnie muzyczne ${ }^{40}$. Publikowanie szkół gry stanowiło istotny element ich działalności. Po ziemiach polskich krążyło w pierwszej połowie stulecia około trzydzieści podręczników pianistycznych, z czego ponad połowę stanowiły prze-

35 Beniamin Vogel, Instrumenty muzyczne w kulturze Królestwa Polskiego. Przemyst muzyczny $w$ latach I8I5-I9I4, Kraków I980, s. II5.

36 Halina Goldberg, O muzyce w Warszawie Chopina, Warszawa 2016, s. 205.

37 Łukasz Gołębiowski, Gry i zabawy różnych stanów w kraju catym, lub niektórych tylko prowincjach, Warszawa I83I, s. 235 .

38 Kufer Kasyldy czyli wspomnienia z lat dziewczęcych, red. Danuta Stępniewska i Barbara Walczyna, Warszawa I974, s. 33.

39 Maria Prokopowicz, „Z działalności księgarzy i wydawców muzycznych w latach I80o-I83I”, w: Szkice o kulturze muzycznej XIX w., red. Zofia Chechlińska, t. I, Warszawa I97I, s. 33- 50, zob. s. 35.

40 Skład Muzyczny Franciszka Klukowskiego, Skład Muzyczny Antoniego Brzeziny oraz Skład Muzyki i Instrumentów Karola Ludwika Magnusa, wszystkie przy ul. Miodowej. 
druki pozycji zagranicznych lub ich tłumaczeń ${ }^{41}$. Polscy autorzy chętnie czerpali z metodycznych propozycji Stiebelta, Hummla, Czernego, Cramera, Kalkbrennera, Moschelesa, Kullaka, Kohlera, Herza czy Huntena. Początkowo dominowały szkoły gry i zasad muzyki dla amatorów, dopiero od końca lat czterdziestych XIX w. przeważać zaczęły bardziej zaawansowane zbiory ćwiczeń i etiud. Ogromna większość autorów postulowała tzw. „mechanistyczną” koncepcję gry, w myśl której wielogodzinne powtarzanie gam, pasaży i schematycznych ćwiczeń doprowadzać miało do zadowalającego poziomu gry.

Jako źródła posłużyły mi podręczniki Karola Kurpińskiego (Warszawa I8ı8, wyd. Franciszek Klukowski), Ignacego Platona Kozłowskiego (Moskwa I832), Jana Nowińskiego (Kraków I839, wyd. Daniel Edward Friedlein), Józefa Nowakowskiego (Warszawa I840, wyd. Rudolf Friedlein) oraz Ignacego Feliksa Dobrzyńskiego (Warszawa I842, wyd. Gustaw Sennewald). To niemal wszystkie zachowane polskie podręczniki do gry na instrumencie z I poł. XIX wieku. Pominąłem Jutrzenkę polska, czyli praktyczna szkote fortepiano Carla Solivy z I826 r., która jest po prostu zbiorem kilku kart z rozpisanymi gamami, pasażami i ćwiczeniami z odpowiednią aplikaturą, bez żadnego komentarza. Nie poddałem również analizie notatek Chopina (Szkice do metody) z okresu od I837-38 do I844-46, które nie złożyły się w podręcznik i w badanym przeze mnie okresie miały stosunkowo niewielki rezonans społeczny, niewykraczający poza krąg jego uczniów. Niestety, co najmniej kilka szkół gry, których ślady znaleźć można w ówczesnej prasie, nie zachowało się do naszych czasów ${ }^{42}$. Jako kontekst porównawczy dla analizowanych źródeł posłużyły mi zagraniczne szkoły gry, które cieszyły się ówcześnie bodaj największą popularnością na ziemiach polskich: Anweisung das Piano-Forte zu spielen Johanna Baptisty Cramera (I8I5), Ausführliche theoretisch-practische Anweisung zum Piano-Forte-Spiel, vom ersten Elementar-Unterrichte an bis zur vollkommensten Ausbilding Johanna Nepomuka Hummla (1828), Méthode Complète et Progressive de Piano Henriego Bertiniego (1840) oraz L'Indispensable du pianiste Antoniego Kątskiego (I848).

Powyższe publikacje cechowała dość schematyczna konstrukcja formalna, na którą składały się następujące komponenty:

I) wstęp o charakterze narracyjnym, który zawierał uzasadnienie powstania danej publikacji oraz jej cele, a także ogólne uwagi dotyczące muzyki i procesu jej nauczania;

2) omówienie podstawowych zasad muzyki, rozszerzone opcjonalnie o opis budowy instrumentu;

3) zestaw ćwiczeń: od prostych do bardziej zaawansowanych, często podzielony na podrozdziały, zazwyczaj z drobnym komentarzem;

4) podsumowanie i uwagi dla ucznia / nauczyciela / rodzica, jeśli nie zostały umieszczone we wstępie;

4I Por.: Michał Kleofas Ogiński, Listy o muzyce, red. Tadeusz Strumiłło, Kraków 1956.

42 Wspomnieć należy tutaj zapowiadany już w 1797 r. na łamach Gazety Warszawskiej podręcznik Karola Bogusława Plaffa Zasady i prawidta praktycznej muzyki na klawikord czy Nowa szkotę na fortepiano Józefa Sikorskiego z I846 roku. 
5) słowniczek niezbędnych pojęć, rozszerzony opcjonalnie o listę polecanych utworów i szkół gry.

Kolejność poszczególnych części była niekiedy zmodyfikowana, jednak wszystkie były zazwyczaj zachowane. Podręczniki polskie właściwie nie różniły się od zagranicznych w zakresie formy, jednak poszczególne części - szczególnie narracyjne - realizowano w nieco odmienny sposób, uwzględniający specyfikę polskiego świata muzycznego. To właśnie te ustępy są z perspektywy historii społecznej najbardziej interesujące. Frapujący bywa również dobór ćwiczebnych miniatur, który stanowił obiekt mojego zainteresowania w perspektywie „komparatystyki kulturowej” (czy pojawiają się polskie tańce narodowe lub utwory polskich kompozytorów?), metodycznej (jak postulowano rozwiązywanie danego problemu technicznego?), czy muzykologicznej (analiza dzieła).

Wydany w warszawskiej drukarni Franciszka Klukowskiego Wyktad systematyczny zasad muzyki na klawikord (1818) Karola Kurpińskiego należy uznać za najstarszy zachowany polski podręcznik do gry na instrumencie klawiszowym. Cieszył się on ogromnym zainteresowaniem i doczekał kilku edycji (wznowienie z roku I828 oraz czterokrotne przedruki w l. 1829-59) ${ }^{43}$. Schemat formalny podręcznika Kurpińskiego, który nie odbiega od zachodnioeuropejskich wzorców, stanowił w późniejszych latach punkt wyjścia dla innych polskich autorów. Celem Kurpińskiego było przede wszystkim „znaczne skrócenie czasu nauki, tak przez jasne wskazanie zasad, jak też przez porządne stopniowanie w ich rozwinięciu" ${ }^{4}$. Autor miał jednak na myśli w zdecydowanie większym stopniu naukę zasad muzyki przy pomocy fortepianu niż doskonalenie wirtuozowskiej biegłości z „teoretycznym uzupełnieniem”, co stanowiło odpowiedź na ówczesne oczekiwania społeczne. Fortepian ${ }^{45}$, jako instrument

43 Na łamach Kuriera Warszawskiego tak komentowano wznowienie nakładu w I828 r.: „szkoła na fortepiano Karola Kurpińskiego jest uznaną za najdokładniejszą w swoim rodzaju, tłumaczy bowiem jasno początkowe zasady muzyki, ułatwia postęp nauki przez porządne rozwijanie tychże zasad, podaje łatwe sposoby pokonywania wszelkich trudności tego instrumentu, najdrobniejsze szczegóły nie tylko że nie są w niej przypomniane, ale owszem nader starannie pozbierane i systematycznym rozmiarem uporządkowane. Stąd też od lat Io znajduje to dzieło najlepsze przyjęcie zwłaszcza od tych, którzy nie mają sposobności mieć nauczycieli muzyki. Ponieważ znaczna liczba rozeszłych egzemplarzy całkiem nadwyrężyła edycję starą, dała się więc uczuć konieczna potrzeba nowej edycji”, zob: Gazeta Warszawska 35 (I828) nr 227 z 24 VIII.

44 Karol Kurpiński, Wyktad systematyczny zasad muzyki na klawikord, Warszawa I8I8, s. VI.

45 Sam autor nie przywiązuje zbyt wielkiej wagi do nomenklatury, często zamiennie stosując nazwy „klawikord” $\mathrm{i}$ „fortepiano". Beniamin Vogel w ramach konsultacji niniejszego artykułu zaznaczyl, że w świetle jego wiedzy Kurpiński był oczywiście w pełni świadom różnicy między klawikordem i fortepianem, jednak nazywanie fortepianu „klawikordem” było rodzajem polskiego regionalizmu. O ile uwaga ta jest w pełni adekwatna w odniesieniu do świata muzycznych profesjonalistów, o tyle mam wrażenie, że w polskiej świadomości społecznej pierwszych dziesięcioleci XIX w. istniała pewna konfuzja dotycząca nomenklatury chordofonów klawiszowych, tym bardziej, jeśli weźmiemy pod uwagę fakt, że część z nich stanowiła nowe wynalazki. Np. w Stowniku jezyka polskiego Samuela Bogumiła Linde znaleźć można jedynie hasło „klawikord”, pod którym de facto kryje się opis fortepianu. Popularność „klawikordu” w określaniu fortepianu spowodowana była przede wszystkim wykorzystywaniem zapożyczenia z języka niemieckiego (klavier). Zamiennie w stosunku do „klawikordu” stosowana była również nazwa „klawicymbał” (od wł. clavicembalo - klawesyn), choć również klawesynu nie można w żadnym wypadku utożsamiać z fortepianem, zob.: M. Bruliński, Szafa -żyrafa - radioodbiornik, s. I4. 
„uważany za najbardziej ogólny”" był dla osiągnięcia takiego celu dydaktycznego instrumentem bezkonkurencyjnym. Kilka lat po opublikowaniu dzieła zdarzyło się kompozytorowi narzekać na nadmiar pianistów wirtuozów w Instytucie Muzyki i Deklamacji. Kurpiński wskazywał na brak ich społecznej przydatności w „sprawie narodowej”: "powiększenie liczby fortepianistów nie jest pożądane ani dla sztuki, ani dla kraju, ani dla narodowej moralności; jest to czysty mechanizm i tak aż nadto rozszerzony" ${ }^{47}$. Dla autora pierwszego polskiego podręcznika do gry na fortepianie głównym (i jedynym) celem kształcenia owego „mechanizmu” miała być umiejętność akompaniamentu do pieśni i wyjątków z oper oraz „funkcjonalna” możliwość wykonania prostych tańców narodowych ${ }^{48}$ podczas salonowych spotkań. Obecność w polskich podręcznikach szeroko rozumianych postulatów patriotycznych stanowi istotną różnię w stosunku do zagranicznych, zdecydowanie bardziej kosmopolitycznych odpowiedników, często pozbawionych elementów regionalnych czy folklorystycznych. W tym kontekście warto zwrócić uwagę na „patriotyczny” dobór utworów w praktycznej części Wyktadu, gdzie obok kilku miniatur Ignaza Pleyela i Carla Czernego pojawiają się polonezy, dumki, krakowiaki i tańce śląskie.

Godny uwagi jest również erudycyjno-anegdotyczny wstęp do Wyktadu, który wywodzi się z oświeceniowej tradycji. Kurpiński opisuje w nim wizytę chłopca, Ignacego. Owego młodego człowieka zauroczyła gra na klawikordzie starszej córki stryja. Zabiegając o jej względy, postanowił udawać przed nią znawcę sztuki muzycznej; jego niewiedza została jednak łatwo zdemaskowana. Aby zdobyć serce młodej damy, chłopiec postanowił zwrócić się do autora Wyktadu systematycznego o pomoc. Ów, nie pozostawiając go w potrzebie, niezwłocznie przystępuje do eksplikacji muzycznych zagadnień. Wprowadza zarazem czytelnika w świat muzyki, zaczynając objaśnienia od etymologii ${ }^{49}$. Podczas opisu znaczenia muzyki w starożytnym Egipcie Kurpiński eksponuje moralną siłę muzyki, wskazując, że procesu jej nauki nie można sprowadzić do „klepania pasaży”so (które de facto w dalszych ustępach dziełka postuluje). W erudycyjnym wstępie nie zabrakło również miejsca dla takich postaci, jak Sokrates czy Chrystus. Nauka gry na instrumencie klawiszowym już wówczas zostaje przedstawiona jako niezbędna umiejętność światłego i kulturalnego człowieka, bez względu na płeć.

Z perspektywy społecznych obserwacji istotny jest pragmatyczny powód powstania podręcznika, przywoływany przez niemal wszystkich późniejszych autorów: $W y$ ktad powstał po to, „aby wielu niebędących w stanie utrzymywać nauczyciela, mogło przy rozważnej pracy uczyć do pewnego stopnia samych siebie, a później i drugich”sr.

46 K. Kurpiński, Wyktad systematyczny, s. VI.

47 Zob.: Tygodnik Muzyczny I (I82I) nr 3, s. 3.

48 Przez „funkcjonalność” rozumiem tutaj akompaniament do tańca.

49 Przy tej okazji odwołuje się do łaciny i greki, a także świata arabskiego oraz do tajemniczego Orientu.

so K. Kurpiński, Wyktad systematyczny, s. V i nast. muzyka bowiem „bawiąc, łagodzi uczucia i wpływa na obyczajność, czyli wzajemne ułagodzenie stosunków".

5I Ibid. 
Kurpiński - jako reprezentant edukacji instytucjonalnej - miał świadomość, że grupa osób, które pragną uczyć się gry mimo braku funduszy na skorzystanie z pomocy metrów, jest bardzo liczna, zaś system szkolnictwa muzycznego nie jest w stanie zaspokoić rosnącego zapotrzebowania społecznego, które kompozytor mógł jedynie intuicyjnie wyczuwać. Kurpiński wiedział również, że społeczny transfer „kompetencji pianistycznej" odbywa się także między osobami, które posiłkować się będą wyłącznie wiedzą zaczerpniętą z podręcznika, nigdy nie zetknęły się i prawdopodobnie nigdy nie zetkną z profesjonalnym nauczycielem gry. W opisanych zjawiskach kompozytor upatrywał jednak, w odróżnieniu od późniejszych autorów, raczej wyzwanie niż problem, co być może powodowała jego odrobinę naiwna wiara w dogmaty oświeceniowego racjonalizmu.

W ramach anegdoty warto nadmienić, że - jak zauważyła Magdalena Dziadek - Wyktad stał się jednym ze źródeł konfliktu między Kurpińskim a Elsnerem, który nie zatwierdził podręcznika do użytku uczniów Szkoły Głównej Muzyki, co spowodowało zerwanie przez Kurpińskiego dydaktycznej współpracy z kierującym placówką Elsnerem ${ }^{52}$.

$\mathrm{Z}$ dziełem Kurpińskiego wiele wspólnych cech dzieli Szkota teoretyczna i praktyczna na fortepiano, prowadzaca stopniami od pierwszych początków do najwyższych trudności Ignacego Platona Kozłowskiego ${ }^{53}$. Podręcznik wydany został w I832 r. w Moskwie, w której pianista znany już wówczas na ziemiach polskich i rosyjskich „z gruntownego uczenia na fortepiano" 54 przebywał po ukończeniu petersburskich studiów u Johna Fielda; ślady tej relacji niechybnie w publikacji znajdziemy, podobnie jak chętnie cytowane wskazówki z podręcznika Hummla (I828) ss. Dla autora Szkoty teoretycznej i praktycznej kluczowy w uprawianiu muzyki był aspekt moralny i kwestie patriotyczne ${ }^{56}$. Również śladem Kurpińskiego, Kozłowski opatrzył swoje dzieło erudycyjnym wstępem, w którym pojawia się wielu wybitnych przedstawicieli świata antycznego. W późniejszych polskich podręcznikach tradycja sięgania do antyku właściwie zanika, podczas gdy

52 M. Dziadek, Od Szkoty Dramatycznej, s. 46.

53 Ignacy Platon Prokop Kozłowski (I786-I859), uczeń Johna Fielda w Petersburgu, działał jako nauczyciel na Podolu i Wołyniu. Wraz żoną, Teresą, również uczennicą Johna Fielda, prowadził żeńską pensję w Werkach (1820-26) oraz w 1. I826-27 pensjonat w Wilnie. Następnie działał w Petersburgu i Odessie. W I828 r. osiedlił się w Moskwie, gdzie również udzielał lekcji gry na instrumencie jako metr. Bywał w salonie Marii Szymanowskiej i spotykał się z Adamem Mickiewiczem.

54 Por.: „Rozmaitości”, Tygodnik Petersburski 3 (I832) nr 64, s. 4I2.

55 „Korzystałem [...] z Hummla, który w tem dziele ogromnem i kosztownem wiele nowych i pożytecznych udzielił prawideł. Łączyłem tu także owoce osobiście zebrane z nauki sławnego Fielda, pierwszego z dzisiejszych fortepianistów, którego oryginalny a świetny rodzaj exekucyi, nikomu dotąd nie był dostępny" - tutaj Kozłowski rzeczywiście miał rację, bowiem w najbardziej popularnych na ziemiach polskich podręcznikach niemieckich rzadko sięgano do wskazówek pianistycznych Fielda, zob.: Ignacy Platon Kozłowski, Szkota teoretyczna i praktyczna na fortepiano, prowadzaca stopniami od pierwszych początków do najwyższych trudności, Moskwa I832, s. II.

56 Por.: ibid., s. I: „A lubo tak powszechne garnienie się do Muzyki można by dotąd przypisywać w znacznej części zwyczajowi i modzie; jednak zwracając uwagę na wysokie zdolności i charakter moralny Polaków, wnosić należy, że im muzyka tak ważną być powinna, jako niegdyś Grekom”. 
w podręcznikach zachodnioeuropejskich jest w ogóle znacznie słabsza, co świadczyć może o różnicach w recepcji myśli oświeceniowej i romantycznej w polskim, rosyjskim i zachodnioeuropejskim kręgu muzycznym.

W ciągu kilkunastu lat między ukazaniem się Wyktadu Kurpińskiego a publikacją Szkoty teoretycznej i praktycznej, muzyka - zdaniem Kozłowskiego - bardzo się w Polsce upowszechniła, stając się „najulubieńszą zabawą, nawet cząstką wychowania, osobliwie płci pięknej”. Pierwszy z autorów nie rozpisywał się specjalnie o szczególnej predylekcji kobiet do fortepianu, która dla drugiego z nich była już zjawiskiem godnym odnotowania - zwrócił na nią uwagę w podręczniku kilkukrotnie ${ }^{57}$. Także w zapowiedzi Szkoty w Tygodniku Petersburskim znaleźć można informację, że dzieło przypisane jest „Polkom wdziękami i sztuk pięknych ozdobami słynącym"s8. Domniemywać zatem należy, że aksjologiczny związek kobiety z fortepianem na ziemiach polskich znacznie umocnił się właśnie w trzecim dziesięcioleciu XIX wieku. Nie jest znany dokładny nakład podręcznika Kozłowskiego, jednak przez wzgląd na fakt, że dostępny był w „Warszawie, Krakowie, Lwowie, Poznaniu i Wilnie w magazynach muzycznych; w Litynie na Podolu u Autora, w Moskwie w księgarni Semena, w Petersburgu w księgarni W. Graffe i księgarni J. Slenina”s9, przypuszczać można, że trafił do większej liczby zainteresowanych niż utwór Kurpińskiego, co - abstrahując od kontekstu płci - świadczyć może o błyskawicznej ekspansji fenomenu fortepianu w ogóle na ziemiach polskich.

O ile na podstawie nawet pobieżnej analizy można stwierdzić, że podręcznik Kurpińskiego powstał z myślą o starszej młodzieży lub osobach dorosłych, o tyle publikacja Kozłowskiego przeznaczona była „dla rodziców, którym nieobojętne jest wykształcenie w dzieciach jednej z najpiękniejszych własności duszy ludzkiej, daru czucia muzyki”, a także „dla nauczycieli grania na fortepiano” oraz „wielu z młodzi, co wyniesione z domu początki muzyki odłogiem puściła i dziś tego żałuje"6o. Karol Kurpiński podchodził do pianistycznego samokształcenia za pomocą podręczników z ostrożną nadzieją i świadom był, że szerokie grono czytelników korzystać będzie z jego podręcznika bez fachowej pomocy metra fortepianu. Ignacy Platon Kozłowski inaugurował postawę typową dla późniejszych autorów, wyznając z boleścią, że „u nas pomimo pięknego zapału i wielkich do muzyki zdolności, rzadko zdarza się słyszeć dobrze grających na fortepianie, co z dwóch zdaje się pochodzić przyczyn: że jest mało dobrych nauczycieli, i że nie ma dobrych dzieł elementarnych"6r. Z całą pewnością możemy ufać diagnozie doświadczonego pedagoga. Poza sygnalizowaną kwestią peryferyjności polskiego świata pianistycznego, uczeń Fielda jako wprawny wirtuoz

57 Trudno się mu dziwić, skoro uważał, że „ze wszystkich rodzajów muzyki instrumentalnej, fortepianowa, płci pięknej najwłaściwsza, a ta najbardziej w ostatnich czasach udoskonaloną i upowszechnioną została", ibid., s. II.

58 Por:: „Rozmaitości”, Tygodnik Petersburski 3 (I832) nr 64, s. $4 \mathrm{I} 2$.

59 Ibid.

6 o Ibid.

6I I.P. Kozłowski, Szkota teoretyczna i praktyczna, s. II. 
zdawał sobie już sprawę - w kontraście do odrobinę naiwnego na tej płaszczyźnie Kurpińskiego - że nauka gry na instrumencie wyłącznie przy pomocy podręcznika jest zadaniem karkołomnym, dlatego starał się także „ile możności jak najdokładniej wszystkie prawidła objaśniać i w szczegółach każdą rzecz opisywać, dla zaradzenia mogącemu się wydarzyć po wsiach niedostatkowi dobrych nauczycieli”"62. Kurpiński po raz pierwszy w polskim podręczniku do gry na instrumencie, który otwierał możliwość pianistycznego samokształcenia na warstwy niższe niż arystokracja, wpisywał naukę gry na fortepianie w kanon kompetencji człowieka kulturalnego. Dla Kozłowskiego obecność fortepianu w katalogu rzeczy i idei, którymi otacza się człowiek światły, wydaje się już niemal dogmatem. O tym, że poruszamy się w kręgu piękna, świadczyć może niepozorny ustęp z zapowiedzi podręcznika, który dotyczy jego ceny. Autorzy powiedzieliby, że jest za wysoka, lecz „wzgląd na ozdobność wydania, na dobroć papieru, czystość druku i litografii każe nam wnosić, że autor miał wielki nakład do poniesienia"63. Interesujące jest, że Kozłowski wspomina o wsiach; o ile obecności fortepianu w środowiskach miejskich XIX w. nie sposób nie dostrzec, o tyle wciąż stosunkowo mało przekazów - poza ikonografią - służyć może jako źródło do badania ról i funkcji instrumentu w kręgach ziemiańskich, które niewątpliwie na myśli miał w tym miejscu autor. Wątek edukacji pianistycznej oraz społecznej recepcji fenomenu fortepianu poza większymi miastami Królestwa Kongresowego, także poza perspektywą „klasową”, z pewnością wart jest przebadania. Ów „,niedostatek dobrych nauczycieli” dotykał jednak przede wszystkim miast. Kozłowski wskazywał, że „muzyk grający tylko na skrzypcach, flecie, organach, lub innym instrumencie, nie może dawać lekcji na fortepianie, gdyż ten zupełnie różni się od innych instrumentów”"64. Ta obserwacja, która z perspektywy współczesnego czytelnika trąca komunałem, jest świadectwem istotnego problemu w ówczesnym polskim krajobrazie muzycznym, o którym wspominałem już wcześniej.

Dość „idealistycznie” Kozłowski postulował, aby w kształceniu pianistów wiodące role odgrywali trzej aktorzy: nauczyciel ${ }^{65}$, korepetytor ${ }^{66}$ oraz sam adept pianistycznej sztuki. Taki model wymagał z pewnością znacznego nakładu finansowego. Gdy połączymy ową propozycję z faktem, że podręcznik wydany był jednocześnie w języku polskim i francuskim - domniemywać możemy, iż Szkota teoretyczna i praktyczna prze-

$62 \overline{\text { Ibid., s. II. }}$

63 „Rozmaitości”, Tygodnik Petersburski 3 (I832) nr 64, s. $4 \mathrm{I2}$.

64 I.P. Kozłowski, Szkota teoretyczna i praktyczna, s. III.

65 Nauczyciel - koniecznie pianista - udzielać miał co najmniej dwóch lub trzech godzinnych lekcji danemu uczniowi w tygodniu. Miał podczas nich przekazywać uczniowi szczegółowe wskazówki dotyczące ćwiczenia.

66 Wedle postulatów Kozłowskiego, „korepetytor [...] może być i nie biegły w muzyce, byleby umiał trochę grać na jakimkolwiek instrumencie”, ibid., s. IV. Mógł być to zatem rodzic lub dowolna inna osoba ze środowiska ucznia, która choćby w nieznacznym stopniu opanowała grę na jakimkolwiek instrumencie i była w stanie egzekwować od ucznia realizację wskazówek nauczyciela. 
znaczona była w zdecydowanie większym stopniu dla arystokracji i ziemiaństwa niż wyraźnie mieszczański - i pod tym względem przełomowy - podręcznik Kurpińskiego.

$\mathrm{U}$ progu lat trzydziestych znacznie upowszechniło się wykorzystanie fortepianu w kameralistyce, co również znalazło odbicie w Szkole teoretycznej i praktycznej. Wielką popularnością cieszyły się rozmaite transkrypcje na cztery ręce, które - przy niewielkiej trudności - umożliwiały przeniesienie do salonu dźwięków ulubionych utworów. Autor przestrzegał jednak, aby nie grywać zbyt wcześnie uwertur; $\mathrm{w}$ „sonatkach zaś lub innych sztuczkach na cztery ręce, dla wprawiania biegłości pożytecznych”, uczniowi towarzyszyć powinien ,zawsze nauczyciel lub kto inny mocny w takcie [...]"67. Kozłowski radził także, ażeby „kilka razy na rok [uczeń - M.B.] grał tria, kwartety i inne sztuki z akompaniamentem, co jest nieodbicie potrzebnym dla wzmocnienia się w takcie i nabycia pewności siebie" ${ }^{68}$. Te i podobne uwagi stanowią cenne świadectwo wykonywanego na przełomie lat dwudziestych i trzydziestych w polskich salonach repertuaru.

Jako pierwszy autor w historii polskich szkół gry na fortepianie, uczeń Fielda poświęcił kilka akapitów kwestii doboru instrumentu do ćwiczeń ${ }^{69}$, co stanowi niezbity dowód systematycznego wyostrzania obrazu instrumentu w świadomości społecznej. Wiele osób ze środowiska Kozłowskiego już wówczas, na przełomie trzeciego i czwartego dziesięciolecia XIX w., pracowało na fortepianach „starych, rozklepanych"7o, co świadczyć może o stosunkowo wczesnym pojawieniu się instrumentów w jego kręgu. Kolejnym utrapieniem był w ocenie autora rozmiar klawiatury: z tego względu „niezdatne są fortepiany czworo-granne, których klawisze są węższe niż w pantalionach zwyczajnych"7r. Ta uwaga może natomiast stanowić przyczynek do studiów nad „transferem technologicznym” między budowniczymi fortepianów na ziemiach polskich i rosyjskich. Interesująca z perspektywy historii fortepianu u progu lat trzydziestych, jak również z perspektywy relacji z Johnem Fieldem wydaje się diagnoza dotycząca fortepianów wiedeńskich: „dziś [...] nie tylko tamtym [z mechaniką angielską - M.B.] dorównały, lecz nawet przewyższyły"72. Kozłowski postulował również zakup specjalnych ław do fortepianów, które ułatwiałyby naukę dzieciom. Innowacją było również dostrzeżenie „muzycznych narzędzi” do doskonalenia aparatu gry, jak chiroplast Logiera. Porównując społeczny obraz fortepianu i edukacji pianistycznej wyłaniający się z podręcznika Kozłowskiego do Wyktadu systematycznego Kurpińskiego, zaobserwować możemy znaczne zwiększenie dynamiki rozwoju właściwie wszystkich obszarów, na których objawiał się fortepian w ówczesnej kulturze polskiej.

$\begin{array}{ll}67 & \text { Autor ma oczywiście na myśli drugą partię, ibid. } \\ 68 & \text { Ibid., s. VIII. } \\ 69 & \text { Ibid. } \\ 70 & \text { Ibid. } \\ 71 & \text { Ibid. } \\ 72 & \text { Ibid. }\end{array}$ 
Kolejną ważką pozycją jest Nowa szkota na fortepian obejmująca zasady muzyki, która wraz z uwagami tyczącymi się gry fortepianowej, przestrogami dla początkujacych nauczycieli i rodziców i dla dopetnienia wtasnej ciekawszych nauki z celniejszych teoretyków zebrat i utożyt w trzech częściach Jan Nowiński. Tytuł podręcznika Nowińskiego ${ }^{73}$ zdradza istotne punkty wspólne z dziełem Kozłowskiego w odniesieniu do adresatów obu szkół. Trzyczęściowe dzieło krakowskiego pianisty i doświadczonego pedagoga przeznaczone było jednak w znacznie większym stopniu dla pedagogów i „korepetytorów” niż samych uczniów czy rodziców ${ }^{74}$. Nieprzypadkowo w tytule pojawia się przymiotnik „nowa” - interpretować go można jako jeden z elementów nacisku na „innowacyjność” i „nowoczesność” kształcenia pianistycznego w pianistycznych narracjach związany z ośrodkiem krakowskim. Pierwszą część Nowej szkoty stanowi rozbudowany na ówczesną skalę podręcznik ze szczegółowym wykładem teoretycznym; druga to zbiór miniatur fortepianowych z obszernym komentarzem, trzecia zaś - wybór ćwiczeń z podanym palcowaniem. Pierwsze dwie części wydane zostały przed I840 r., ostatnia w roku I842. W tym czasie swoje szkoły opublikowali Józef Nowakowski (I840) oraz Ignacy Feliks Dobrzyński (I842). Nie mógł Nowiński przejść wobec tego faktu obojętnie - stąd w trzeciej części znajdziemy wnikliwy komentarz krytyczny do obu dzieł. Do ułożenia Nowej szkoty krakowski pedagog miał

73 Zachowały się jedynie strzępy informacji o Janie Nowińskim. Jego postać wspomina Albert Sowiński, nie podając dat urodzenia i śmierci: „nauczyciel muzyki w Szkole technicznej w Warszawie”. Nie wiadomo, jaką placówkę Sowiński miał na myśli i skąd zaczerpnął informację na temat działalności Nowińskiego w Warszawie, co jest tym bardziej zastanawiające, że podręcznik Nowińskiego nie został wydany przez żadną z warszawskich drukarni. Prawdopodobne jest, że pomylił Warszawę z Krakowem, gdzie wydany został podręcznik Nowińskiego. Z Almanachu muzycznego Krakowa I780-I9I4 Józefa Reissa (t. I-2 Kraków I939) wiadomo natomiast, że pianista Jan Nowiński występował w l. I8I7-I9 w Krakowie na koncertach Towarzystwa Przyjaciół Muzyki (zob. ibid., t. I, s. 30, t. 2, s. 88), a zatem z krakowskim środowiskiem muzycznym miał styczność dość wcześnie. Mimo iż w publikacjach Przybylskiego ani Wąsacz-Krztoń nie pojawiają się żadne dane dotyczące Jana Nowińskiego w kontekście którejkolwiek z krakowskich szkół muzycznych, domniemywać można, że z nieokreślonych powodów (np. krótki czas pracy) informacja o współpracy Nowińskiego z kierowaną przez Mireckiego szkołą nie zachowała się, a Sowiński pomylił w kontekście „Szkoły Technicznej” wspomniane miasta. Z całą pewnością Nowiński znał twórczość i działalność Mireckiego, ponieważ do swojego podręcznika włączył jego miniaturę fortepianową (cz. II, s. I6). Wszystkie pozostałe informacje u Sowińskiego związane są z Nową Szkotą na fortepian, „wydaną w roku I839 u Spiesa, która miała kilka edycji w Krakowie, we Lwowie i w Wilnie. Ta szkoła wyszła w trzech sposzytach, zawiera teorię, praktykę i układ paleczny. Napisana czystą polszczyzną, wytłuszcza jasno zasady gry fortepianowej”, zob.: A. Sowiński, Stownik muzyków polskich, s. 289.

74 Świadczą o tym liczne wskazówki z zakresu psychologii nauczania, szczególnie w odniesieniu do procesu dydaktycznego, jak również utyskiwania na krnąbrnych rodziców, zob.: Jan Nowiński, Nowa szkota na fortepian obejmująca zasady muzyki, która wraz z uwagami tyczącymi się gry fortepianowej, przestrogami dla początkujących nauczycieli $i$ rodziców $i$ dla dopetnienia wtasnej ciekawszych nauki z celniejszych teoretyków zebrat $i$ utożyt $w$ trzech częściach, cz. I, Kraków ok. I839, s. V i VIII. Niedostosowanie podręcznika do potrzeb samokształcenia młodzieży wytykał później Nowińskiemu wielokrotnie Ignacy Feliks Dobrzyński. Owo „niedostosowanie” wynikać mogło z chęci wykorzystania podręcznika w kursie kształcenia instytucjonalnego (Szkoła Śpiewu Mireckiego), jednak jest to jedynie wstępna hipoteza, wymagająca weryfikacji w dalszych badaniach. 
zostać „wezwany przez wydawcę”, co sugeruje spory popyt na podobne dzieła. Nadmienić należy, że wcześniejsze szkoły gry powstawały z inicjatywy ich autorów. Podręcznik Nowińskiego to najbardziej kompletna i obszerna szkoła gry na instrumencie wydana na ziemiach polskich w I poł. XIX w., jeśli nie w całym stuleciu ${ }^{75}$. Ponadto oryginalna, trzyczęściowa struktura podręcznika stanowiła niezaprzeczalny dowód na przywołaną w tytule innowacyjność. Nowa szkoła to także jeden z niewielu oryginalnych polskich podręczników do gry na fortepianie w kręgu galicyjskim, który z oczywistych względów zdominowany był przez rozkwitającą literaturę niemiecką.

Podobnie jak poprzednicy, krakowski pianista spory nacisk kładł na kwestie moralne i patriotyczne. Trudno zauważyć je w toku dydaktycznych instrukcji, jednak widać jak na dłoni przy doborze repertuaru ćwiczebnego. Nowiński polecał uczniom nie tylko „gruntowną naukę i zgłębienie dzieł Beethovena, Hummla, Webera, Fielda, Moschelesa, Pixisa, Chopina, Schummana [sic], Mendelssohna-Bartholdy, Henselta, Thalberga i innych" ${ }^{76}$; w części praktycznej podręcznika dostrzec można przede wszystkim wyraźną specyfikę polską - szeroki zbiór melodii ludowych i pieśni religijnych77. Wskazać jednak należy dwie istotne różnice w stosunku do dzieła Kurpińskiego: u Nowińskiego dostrzec można znacznie mniej elementów dydaktycznej tradycji oświeceniowej, jak choćby odwołania do antyku czy kunsztowne wyjaśnienia etymologiczne, zaś obecny u Kurpińskiego wątek pieśni patriotyczno-religijnych i tańców narodowych w kontekście studiów pianistycznych wykracza u Nowińskiego daleko poza skromne ramy „funkcjonalne” i stanowi wprowadzenie do gry wirtuozowskiej, którą autor Wyktadu systematycznego żarliwie potępiał. Również w tym sensie Nowa szkota miała być podręcznikiem „nowoczesnym”.

Z perspektywy społecznej historii muzyki podręcznik Nowińskiego może posłużyć jako frapujący materiał dla badacza statusu społecznego nauczyciela gry na instrumencie. Jego autor był znanym, doświadczonym i cenionym metrem, nie tylko w krakowskim środowisku muzycznym, podobnie zresztą jak Kozłowski. Prawdopodobnie - śladem Kurpińskiego i Kozłowskiego - miał styczność z edukacją instytucjonalną. Z jednej strony próbował zaradzić niekompetencji wielu kolegów po fachu ${ }^{78}$, chętnie cytując

75 Owa kompletność objawia się w kompleksowym podejściu do kwestii związanych z organizacją i psychologią pracy z uczniem, a także w bazie źródłowej, z jakiej Nowiński korzystał. Powołuje się na publikacje kilkunastu zachodnioeuropejskich autorów, z których część entuzjastycznie aprobuje, inne zaś poddaje dotkliwej krytyce. Dokonuje także kompetentnego przeglądu różnych metod nauczania, ustosunkowując się do modnej ówcześnie metody beznutowej, której gorącą orędowniczką była Klara Schumann. Nadmienić należy, że Nowiński był wielkim fanem pedagogicznych postulatów Kalkbrennera, którego wielokrotnie na kartach swego dziełka cytował.

76 J. Nowiński, Nowa szkota, cz. II, s. 53.

77 Np. pieśni religijne: Szczęśliwy kogo Opatrzność Boska, Nie pogardzaj ubogiemi, Salve Regina; pieśni, piosnki i melodie ludowe: Już śpiewasz skowroneczku, Już stońce tyle razy wracato, Czas do domu czas, Gaski (nad woda w wieczornej porze), Wszystko z czasem ulatuje, Chtopczyk na kijku z biczykiem w ręku oraz polskie tańce stylizowane: krakowiak, dumka, mazur, polonez.

78 „Nie każdy bowiem powziął troskliwe muzyczne ukształcenie [...]; niejeden z młodszych kolegów, biorąc się do uczenia muzyki fortepianowej, liczne popełnia usterki, nim trafi na drogę przyzwoitego postępowania”, J. Nowiński, Nowa szkota, cz. I, s. II. 
ustępy z Ignacego Platona Kozłowskiego ${ }^{79}$, z drugiej - uskarżał się na lekceważące traktowanie metrów przez rodziców uczniów, których „wpływ może być i szkodliwy, gdy wymagają tylko wykonania tańców modnych i sztuk wystawnych, gdy wdzierają się w prawa nauczyciela i bez zbędnego stanowiska wyrokują o sztuce" ${ }^{\text {". }}$. Mimo trudności i wyzwań, na jakie narażony był nauczyciel w relacji z rodzicem i uczniem, Nowiński był zwolennikiem podobnego, nowoczesnego modelu współpracy w procesie dydaktycznym, co Kozłowski (nauczyciel - pianista, rodzic - korepetytor, uczeń), na którym w nieco zmienionej formie zasadza się cały system współczesnego kształcenia instrumentalistów. Niewątpliwie krakowianin był nauczycielem z powołania, który kierował się szlachetnym etosem pedagogicznym: postulował, aby w sytuacji, kiedy „nie wady, ale brak funduszu utrudnia naukę muzyki”, dopomóc uczniowi w miarę możliwości ${ }^{81}$. Śladem poprzedników dostrzegał oczywiście, że nie każdy uczeń może sobie pozwolić na korzystanie z usług profesjonalnego nauczyciela, jednak trudno określić jego dzieło jako odpowiednie dla celów samokształcenia w rozumieniu, jakie proponował ponad dwadzieścia lat wcześniej Kurpiński. Świadczyć to może o znacznym wzroście liczby metrów gry na fortepianie w ciągu dwudziestolecia dzielącego oba podręczniki.

Nowa szkoła to pierwszy polski podręcznik, w którym znaleźć można wskazania dotyczące improwizacji. Nowiński wspominał m.in. o zwyczaju preludiowania ${ }^{82}$, a także przestrzegał, aby młodzi pianiści „nie odważali się zbyt wcześnie i śmiało z improwizowaniem publicznie, ale tylko wobec zaufanych przyjaciół; żeby się nie spieszyli z wydaniem swoich pierwszych prac na widok publiczny" ${ }^{3}$. U progu lat czterdziestych nieudolne improwizacje salonowe stanowić musiały prawdziwą plagę muzycznych spotkań, bowiem o rozwadze w procesie improwizacji wspominali właściwie wszyscy autorzy późniejszych szkół gry, zaś śladów wskazówek dotyczących improwizacji próżno szukać w podręcznikach wcześniejszych. Fakt ten można odczytywać jako świadectwo zanikania estetycznego idiomu oświeceniowego na rzecz paradygmatu romantycznego z kultem improwizującego wirtuoza w tle.

Szkota na fortepian podtug celniejszych autorów z dodatkiem ćwiczeń wtasnego ukta$d u$ Józefa Nowakowskiego ${ }^{84}$ jest pozycją najmniej oryginalną z przeanalizowanych dotychczas. W dużej mierze stanowi ona tłumaczenie metody Franza Hüntena, Nouvelle

84 Józef Nowakowski, Szkota na fortepian podtug celniejszych autorów z dodatkiem ćwiczeń wtasnego uktadu, Warszawa I840. Co interesujące - wszystkie polskie encyklopedie muzyczne - za Stownikiem Sowińskiego - podają błędną datę wydania podręcznika (I850, zob. np.: Encyklopedia muzyki, red. Andrzej Chodkowski, Warszawa 2006, s. 6I3). Nowakowski (I800-65) związany był z Warszawą: studiował u Elsnera i Würfla, był kolegą Chopina ze szkolnej ławy. W 1. I833-46 odbywał liczne podróże, jednocześnie nauczając w Instytucie Aleksandryjskim Wychowania Panien (I840-44). Po I848 r. osiadł na stałe w Warszawie, gdzie zyskał sławę jednego z najbardziej popularnych nauczycieli gry na fortepianie, piastując stanowisko profesora gry fortepianowej w Instytucie Muzyki (I86I-64), zob.: A. Sowiński, Stownik muzyków polskich, s. 286-288. 
méthode pour le piano-forte op. 60 (I833). Może to mieć związek z wrażeniami, jakie musiały na autorze wywrzeć zdobycze niemieckiej i francuskiej pedagogiki fortepianowej podczas europejskich podróży, jak również z jego przygotowaniami do nauczania gry na fortepianie po powrocie do kraju. Powierzchowność oraz niedokładność autora Szkoty poddał dotkliwej krytyce Jan Nowiński w trzeciej części swojego podręcznika ${ }^{85}$. Nowakowski korzystał już nie tylko z wcześniejszych szkół (m.in. Hummla) - sięgnął również jako jeden z pierwszych polskich autorów po francuskojęzyczną szkołę Bertiniego, wydaną w Paryżu raptem kilka miesięcy wcześniej. Zatem mimo iż profesjonalni muzycy polscy uskarżali się na peryferyjność rodzimego środowiska muzycznego względem zachodnioeuropejskich centrów, byli znakomicie poinformowani o wszelkich pianistycznych „nowinach ze świata”.

Do lat czterdziestych zagraniczne podręczniki były tłumaczone na język polski stosunkowo rzadko. Rodzime wydania dzieł Cramera i Hummla były najczęściej przedrukami wydań niemieckich. Nie dziwi to specjalnie, jeśli weźmiemy pod uwagę przynależność znajomości języków obcych do tego samego kanonu „człowieka kulturalnego”, co umiejętność gry na instrumencie. Nowakowski dostrzegł na tym polu dwa problemy: po pierwsze „szkoły Bertiniego i Hummla [...], prawdziwie wzorowo opracowane, lecz takowe raczej dla kształcącego się zostały napisane; amatora, który w sztuce szuka jedynie rozrywki, ogromem swoim i mniej przejrzystym wykładem odstręczają" ${ }^{36}$. Ponadto „wydane są w językach, których dokładnej znajomości, pomimo wielkiego u nas upowszechnienia, od dzieci zwłaszcza, wymagać nie można”. Autor nie pomylił się, jeśli chodzi o wyczucie popytu na szkoły gry w ojczystym języku, bowiem u progu lat czterdziestych opublikowane zostały aż trzy, a wszystkie cieszyły się sporym zainteresowaniem czytelników. Przy tym - co może wydać się zaskakujące - jego podręcznik uznać należy jednak za najbardziej „kosmopolityczny” z dotychczas opisanych; odsuwał Nowakowski na zdecydowanie dalszy plan żywe wciąż u Kurpińskiego i Kozłowskiego kwestie moralne i patriotyczne. Nawet w wyborze miniatur prawie pominął muzykę polską, poza kilkoma własnymi ćwiczeniami. Precedensowe było natomiast nakierowanie przez przyjaciela Chopina uwagi na dzieci, które stały się po raz pierwszy jednym z bezpośrednich adresatów tego typu dzieła.

Do „dyskursu aksjologicznego” powrócił Ignacy Feliks Dobrzyński ${ }^{87}$ w cieszącej się wielką popularnością publikacji o wymownym tytule Szkota na fortepian poświę-

85 J. Nowiński, Nowa szkota, cz. III, s. I: „w dziele p. Nowakowskiego widać wszędzie nieporządek i nieład; błędnie podane prawidła, powierzchowne, zbyt lekkie dotknięcie głównych zasad. Przesadne mniemania, niezrozumiałe wyrażenia". Nowiński rozwija swoją detaliczną krytykę w przypisach na ponad dwie strony.

86 J. Nowakowski, Szkota na fortepian, s. I.

87 Ignacy Feliks Dobrzyński (I807-67), kompozytor, dyrygent i pedagog. Kształcił się początkowo pod kierunkiem ojca, praktykując w dworskiej orkiestrze hr. Ilińskiego w Romanowie. W i825 r. rozpoczą kształcenie pod kierunkiem Elsnera w Warszawie, z której - przez Poznań - wyjechał do Berlina. Do Warszawy wrócił w I847 r., aby w I852 r. objąć po Tomaszu N. Nideckim stanowisko Dyrektora Opery Warszawskiej. Dobrzyński był niewątpliwie znakomitym i doświadczonym pianistą, o czym świadczą przede wszystkim jego dzieła na fortepian, jak np. Koncert fortepianowy As-dur op. 2. 
cona Rodakom z I842 r. ${ }^{88}$. Kolejny kolega Chopina ze szkolnej ławy postrzegał grę na fortepianie jako nieodzowny element wychowania, także patriotycznego, powracając tym samym do propozycji Kurpińskiego, chociaż w zmienionej formie. Druk jego podręcznika wznawiano w 1. I862, I866 oraz I868; Szkołę wydał w tłumaczeniu niemieckim nawet Breitkopf. Niewątpliwie należy ona do ważnych osiagnięć w historii polskiej dydaktyki pianistycznej. Doskonale zorientowany w europejskim krajobrazie pianistycznym, Dobrzyński chętnie czerpał z ćwiczeń i porad Kalkbrennera i Czernego, uzupełniając je o własny komentarz. W jego podręczniku widać wiele zbieżności ze wskazówkami chopinowskimi ${ }^{89}$, krytycznie odnosił się natomiast do niektórych postulatów Moschelesa i Herza. Wyrażał aprobatę w stosunku do wydanej niewiele wcześniej szkoły Nowińskiego, jako jedyny jej mankament słusznie wskazując „zbyteczną obszerność onej, która utrudza cokolwiek dzieciom naukę"90. Nowiński nie pozostał dłużny; doceniał wprawdzie, że „wiele jest w podręczniku Dobrzyńskiego uwag trafnych”, zwracając równocześnie uwagę, że „tu i ówdzie są opuszczenia, lekkie skazy”. Żałować także należało, zdaniem wytrawnego krakowskiego pedagoga, że „tak znakomity artysta tak szczupłe założył sobie cele w wykonaniu swej pracy" ${ }^{91}$. Polemiki prowadzone przez autorów poszczególnych podręczników, także na łamach prasy, świadczą o wysokiej temperaturze i przyzwoitym poziomie polskiej myśli pedagogicznej oraz o co najmniej umiarkowanym rezonansie społecznym, jaki budziły poruszane zagadnienia.

Dobrzyński zabrał również głos w zapoczątkowanej przez Kozłowskiego dyskusji dotyczącej odpowiedniego wieku do nauki gry. Wskazywał, że wiekiem najwłaściwszym był czas między 7 a 9 rokiem życia, a rozpoczęcie nauki w wieku I2 lat było już zbyt późne, bowiem „ręka i palce trudniej się już kształcą”92. Nieco wcześniejsze rozpoczęcie nauki postulował Nowiński, jako górną granicę stawiając ósmy rok życia ${ }^{93}$. Metodyczne obserwacje Dobrzyńskiego były jednak nieco bardziej zbieżne z praktyką społeczną. Dyskurs o początkach edukacji pianistycznej stanowi jedno ze świadectw profesjonalizacji polskiej dydaktyki pianistycznej.

Szkota Dobrzyńskiego przewidywała ścieżkę pianistycznego rozwoju o orientacji „umiarkowanie profesjonalnej”. Ustęp zamykający dzieło zdradza olbrzymią lukę w systemie ówczesnej edukacji muzycznej, bowiem zgodnie ze wskazówkami autora, „po

88 Taką datę wydania podaje Biblioteka Narodowa, jednak Dobrzyński odnosi się krytycznie do podręcznika Nowińskiego, opublikowanego w 1842 roku. Pierwsze wydanie opisywanego w dalszej części eseju podręcznika Nowińskiego zawiera z kolei odniesienia do publikacji Dobrzyńskiego, zatem, mimo iż trudno ustalić precyzyjnie chronologię wydań, przyjąć należy, że podręczniki te ukazały się w podobnym czasie, najprawdopodobniej około I84I lub I842 r., ponieważ o żadnym z autorów nie wspomina wydany w I840 r. Nowakowski.

89 Z pewnością kolega Chopina ze szkolnej ławy wniósł w Szkole na fortepian poświęconej Rodakom istotny wkład w budowanie chopinowskiego kultu i mitu.

90 Ignacy Feliks Dobrzyński, Szkota na fortepian poświęcona Rodakom, Warszawa I842, s. I.

9I Wszystkie cytaty pochodzą z: J. Nowiński, Nowa szkota, cz. III, s. II.

92 I.F. Dobrzyński, Szkota na fortepiano, s. 24 i nast.

93 J. Nowiński, Nowa szkota, cz. I, s. III. 
przejściu należytym tej Szkoty i obeznaniu się z dziełami Mozarta, Beethovena, Clementiego, Cramera, Hummla, Moschelessa, Herza, Kalkbrenera, Fielda, Onslowa, Spohra, można się puścić drogą Chopina, Thalberga, Liszta, Henselta.... jeżeli w sobie uczujemy siły dostateczne"94. Idąc tropem Nowińskiego, Dobrzyński poświęcił kilka słów krytyki salonowym improwizacjom młodych pianistów, potępiając "nagany godną, najszkodliwszą i najniedorzeczniejszą [...] manię improwizowania wśród młodzieży”, która „obraża nieśmiertelnego Hummla oraz wielkiego geniusza - Chopina!"'s. Żalił się, że polska kultura muzyczna odstaje poziomem od francuskiej czy niemieckiej, bowiem w Królestwie Polskim uznanie zyskują ,,upojeni lichymi pochwałami w pismach periodycznych szarlatani”, którzy „tam skończyli, gdzie inni dopiero zaczynają”96. Ta i inne uwagi Dobrzyńskiego są świadectwem doskwierającego poczucia peryferyjności polskiej kultury muzycznej względem innych krajów europejskich, a zarazem - w zestawieniu z dziełami analizowanymi przeze mnie wcześniej - kolejnym symptomem dynamicznych ówcześnie zmian w społecznej recepcji fenomenu fortepianu. Kiedy wydawany był Wykład systematyczny Kurpińskiego - brak w nim było wzmianek dotyczących improwizacji; po raz pierwszy pojawiają się one w dziele Nowińskiego, u Dobrzyńskiego natomiast złe praktyki improwizacyjne młodych adeptów sztuki pianistycznej stanowią już środowiskowy problem.

Niestety, do naszych czasów nie zachowała się Nowa szkota na fortepian Józefa Sikorskiego, wydana w Warszawie w I846 roku. Jedynym zachowanym podręcznikiem Sikorskiego jest Doręcznik muzyczny ${ }^{97}$, jednak nie jest on poświęcony stricte fortepianowi. Ów podręcznik z dzisiejszej perspektywy określić można jako publikację teoretyczno-popularyzatorską. Doręcznik wprowadzał czytelnika w podstawowe zagadnienia z zakresu teorii muzyki, opisując jednocześnie wiele muzycznych zjawisk i fenomenów ówczesnego świata. Z całą pewnością publikacja Sikorskiego stanowi interesujące źródło do poznania wielu aspektów związanych z historią społeczną tudzież socjologią historyczną muzyki. To właśnie na jego podstawie można stawiać nieśmiałe hipotezy dotyczące tego, co można było znaleźć w Nowej szkole Sikorskiego oraz jaki był jego pogląd na naukę gry. Jednym z deklarowanych przez Sikorskiego celów opublikowania Doręcznika było przekonanie nauczycieli gry na fortepianie do „przyjęcia rozleglejszej metody [...], by nie szybkobiegaczów, tylko pojmujących rzecz kształcili, [...], ileż bowiem muzykalność ogółu by wtedy zyskała?"98. O ile zatem Dobrzyński skarżył się na manieryczne i nieudolne improwizacje młodych adeptów sztuki pianistycznej, o tyle kilka lat późnej - a można domniemywać, że

94 I.F. Dobrzyński, Szkota na fortepiano, s. 59.

95 Ibid., s. 25 .

96 Ibid.

97 Józef Sikorski, Doręcznik muzyczny. Trésciwe przedstawienie muzyki dzisiejszej, ze szczególnym baczeniem na miejscowe potrzeby, przyktadami w nutach do objaśnienia niektórych szczegótów niezbędnymi oraz stownikiem muzycznym, Warszawa I852.

98 Ibid., s. IX. 
już w roku wydania Nowej Szkoty - palącym problemem dydaktycznym, który diagnozował Sikorski, była przesadna fascynacja biegłością muzyczną (co zdaje się być problemem wielu młodych pianistów także dziś). Dla Sikorskiego sam fortepian ${ }^{99}$ był „między strunowymi instrumentami pierwszym [...], panem na polu, na którym inne instrumenta niegdyś znakomite miejsce zajmowały [...]". Instrument ten był „silny budową i przemożny skalą, rozzuchwalony polotem wirtuozów, do wszystkich kombinacji odpowiedni [...], z każdym innym narzędziem w parę stanąwszy, nawet razem ze wszystkimi i starczyć im zdoła”"1oo. Narzędzie muzyczne „zwane fortepianem rozsiadło się dziś pysznie niemal wszędzie, gdzie skromna nawet zamożność muzykę uprawia; czymże było przed osiemdziesięcioma laty, jeszcze dwudziestoma nawet?” ${ }^{\circ}$ - pyta Sikorski. To z pewnością jeden z piękniejszych opisów fenomenu fortepianu w polskiej kulturze I poł. XIX w., a zarazem świadectwo jego niezwykle dynamicznej ekspansji od początku lat trzydziestych. Z kolei ową „skromną zamożność” odnieść można do stale powiększającej się dostępności instrumentu (a zatem: spadku jego kosztów), dzięki którym fenomen fortepianu penetrował coraz niższe kręgi społeczne. „Niezmierne swe upowszechnienie mimo braku ciągłego tonu” fortepian zawdzięczać miał - według Sikorskiego - „bogatej skali”, co „czyni ten instrument do zastosowania w przekładaniu kompozycji napisanych na orkiestrę"'102, a zatem transkrybowaniu. To również istotny szczegół, bowiem jest to jedna z pierwszych w polskiej kulturze jasnych diagnoz związanych z przydatnością fortepianu jako „domowej orkiestry”.

W jednym z dalszych ustępów Doręcznika Sikorski wymienił kompletną panoramę nazwisk związanych ze światem dydaktyki pianistycznej, zarówno zagranicznych (Muzio Clementi, Ludwig van Beethoven, Johann Nepomuk Hummel, Johann Baptist Crammer, Ignaz Moscheles), jak i polskich (Józef Elsner, Karol Kurpiński, Józef Brzowski, Józef Nowakowski, Ignacy Feliks Dobrzyński, Stanisław Moniuszko, Edward Wolff, Antoni Orłowski, Kasper Napoleon Wysocki, Albert Sowiński, Julian Fontana, Antoni Kątski, Franciszek Mirecki, Ignacy Krzyżanowski, Florian Miładowski, Teodor Wodnicki $\mathrm{i}$ - last but not least - Chopin ${ }^{\mathrm{ro3}}$. Enumeracja ta jest istotna o tyle, że przedstawia możliwie pełną konstelację postaci kluczowych dla fenomenu fortepianu i pedagogiki fortepianowej na ziemiach polskich w I poł. XIX wieku. Niemal wszyscy wymienieni Polacy kształcili się pianistycznie w warszawskich lub krakowskich szkołach, co potwierdza doniosłe znaczenie tych instytucji w kontekście profesjonalnej edukacji muzycznej. Tymczasem niemożliwe jest oszacowanie piani-

99 Co interesujące, Sikorski po słowie „fortepian” dopisuje w nawiasie: „pianoforte, cembalo, klavier”. Taka forma zdaje się być dość późnym świadectwem nomenklatury dominującej w I poł. XIX w., gdy wszystkie powyższe nazwy - włączając w to klawikord - wykorzystywane były w odniesieniu do fortepianu.

IOO Ibid., s. 244.

IOI Ibid., s. 269.

IO2 Ibid., s. 244.

IO3 Ibid., s. 245 . 
stów-amatorów, których edukacja pianistyczna opierała się na nauce z podręczników, a którzy często stawali się metrami fortepianu.

Cenne dopełnienie uwag Sikorskiego z Doręcznika stanowią wybrane artykuły z Ruchu Muzycznego. Na jego łamach w I858 r. stawiał pesymistyczną diagnozę dotyczącą polskiego systemu kształcenia muzycznego, z której wyczytać można także ogromną doniosłość znaczenia przeznaczonych dla muzycznych amatorów podręczników do gry: „istotnie rozpacz niemal ogarnia niejedną duszę chciwą nauki, gdy poszukawszy spostrzeże, że nie ma się jak nauczyć. Ludzie rzadcy i wystarczyć nie mogą [...], instytucji wyższej ani jednej! Strach! [...] a w domu? Toć nasze żony, córki, siostry, wszystko to grać uczyło się lub uczy, wszędzie są fortepiany”"I04.

Popularność podręczników do gry na fortepianie stymulowały trzy grupy czynników. Pierwsze związane były z wydawcami. Dzięki sporemu popytowi, druk szkół gry na instrumencie był dla nich zazwyczaj opłacalną inwestycją. Dostrzec można również interes drukarni muzycznych w dłuższej perspektywie czasu, bowiem zwiększanie społecznej kompetencji pianistycznej pozytywnie wpływało na popyt względem utworów fortepianowych. Czytelnicy podręczników, którzy nie byli zainteresowani wirtuozowską biegłością, dostawali od autorów pianistycznych metod złudzenie „łatwego awansu" w grach statusowych dzięki obietnicy nieskomplikowanego i szybkiego zwiększenia swoich kompetencji. Ponadto podręczniki do gry zaspokajały do pewnego stopnia palący problem braku funduszy szerokiej grupy potencjalnych adeptów sztuki pianistycznej, który uniemożliwiał im korzystanie z usług metrów. Autorzy zaś, zyskując popularność, która owocowała na koncertowych i pedagogicznych polach ich działalności, starali się diagnozować i przezwyciężać konkretne problemy, jak brak kompetencji metrów, mechaniczny i „bezduszny” styl gry. Budowali także kapitał merytoryczny, dzięki któremu kompetentni nauczyciele gry na fortepianie stopniowo zyskiwali wyższą pozycję w stratyfikacji społecznej. Stale odwołując się do dorobku poprzedników, polscy autorzy tworzyli również zalążki myśli pedagogicznej, kładąc podwaliny pod gmach polskiej szkoły pianistycznej.

W perspektywie chronologicznej dostrzec można olbrzymie przyspieszenie i wzrost temperatury pianistycznych dyskusji. Zmieniają się również stawiane przez autorów diagnozy problemów pianistycznej edukacji. Pod koniec drugiego dziesięciolecia XIX w. Kurpiński - świadom rudymentarnych braków systemowych - zapewnił solidne fundamenty i wzorce dla późniejszych publikacji. U progu czwartej dekady Kozłowski jako główną bolączkę wskazywał brak wykwalifikowanych nauczycieli oraz „dzieł elementarnych”. Mimo że Nowiński, Dobrzyński i Nowakowski wydali swoje podręczniki w tym

IO4 Józef Sikorski, „Jakim sposobem można się u nas kształcić w muzyce?”, Ruch Muzyczny 2 (I858) nr 42, s. 332. 
samym czasie - diagnozowali inne trudności, co świadczy o niewątpliwej ekspansji fenomenu fortepianu w kulturze polskiej u progu lat czterdziestych XIX wieku. Pierwszy z wymienionych uskarżał się na „obyczajową modę”, która owocowała masowym dyletantyzmem, drugi - na nieudolne improwizowanie rzesz młodych adeptów sztuki pianistycznej. Z kolei niecałą dekadę później Sikorski ubolewał w perspektywie społecznej nad przesadną fascynacją biegłością techniczną. Podobne problemy wskazywane były przez autorów publikacji metodycznych na Zachodzie Europy w analogicznych okresach. Dyskursywna droga, wiodąca od braku muzycznych podstaw do krytyki „pianistycznego szybko-biegactwa”, stanowi kolejny niezbity dowód na dynamiczną ekspansję fenomenu fortepianu na ziemiach polskich w I poł. XIX wieku.

Specyficzną cechą polskich podręczników na tle europejskich odpowiedników był ich wydźwięk patriotyczny oraz obecność elementów religijnych. Oryginalne w skali europejskiej pozostają również erudycyjne wywody Kurpińskiego i Kozłowskiego, wpisujące się w tradycję oświeceniową. Dostrzec można wiele cech wspólnych, które łączą polskie dzieła tego gatunku w kolejnych dziesięcioleciach badanego okresu. Jako frapującą różnicę między kręgiem warszawskim i krakowskim wskazać należy „aspiracje wirtuozowskie” pierwszego z ośrodków wobec nacisku na „nowoczesność” metod kształcenia drugiego.

Obraz wyłaniający się z polskich szkół gry na fortepianie w I poł. XIX w. stanowi cenne dopełnienie społecznej panoramy muzycznej, która znana jest badaczom społecznej historii muzyki z prasy, pamiętników i sztambuchów. Istotnym pojęciem $\mathrm{w}$ analizowanym dyskursie jest peryferyjność instytucjonalna i repertuarowa, wskazywana właściwie przez wszystkich autorów. Mieli oni styczność zarówno z instytucjonalnym, jak i prywatnym wymiarem edukacji, a opublikowane podręczniki stanowiły zazwyczaj summę ich doświadczeń na polu pedagogiki instrumentalnej, dlatego - w moim odczuciu - można ufać ich diagnozom. Z drugiej strony, wskazywaną przez autorów peryferyjność polskiego świata pianistycznego analizować należy przez pryzmat ich europejskich podróży: być może ich aspiracje, kształtowane w największych europejskich ośrodkach pianistycznych, były zbyt wygórowane jak na polskie, „skromne podwórko”. Mimo pewnej - dyskusyjnej - dozy peryferyjności, należy jednocześnie zwrócić uwagę na dynamiczną ekspansję idiomu romantycznego w polskiej kulturze muzycznej, w której rosnące znaczenie fortepianu splatało się z niebywałym wzmożeniem improwizacji przy równoczesnej, stopniowej profesjonalizacji kształcenia i systematycznym wzroście społecznych aspiracji, co znakomicie uwidacznia się na kartach analizowanych podręczników.

Zaskakująco mało w porównaniu z Zachodem Europy znaleźć można w polskich szkołach gry w omawianym okresie informacji o instrumentarium. Jest to tym bardziej zastanawiające, że był to czas niezwykle intensywnych eksperymentów na polu konstrukcji instrumentu. Dziwić może także fakt, że na kartach polskich podręczników próżno szukać jakichkolwiek form promocji konkretnych warsztatów budow- 
niczych fortepianów, którzy na współpracy z autorami szkół gry mogli bardzo wiele zyskać. Wynikać to może z braku rudymentarnej infrastruktury koncertowej, który odróżniał polskich budowniczych od bogatszych warsztatów niemieckich czy francuskich.

Znaczenie podręczników do gry na fortepianie w całokształcie polskiej kultury pianistycznej było dotychczas marginalizowane, prawdopodobnie dlatego, że jego doniosłość nie była reprodukowana właściwie w żadnej wiodącej narracji - ani o wirtuozach w krytyce muzycznej, ani o „hałasie” produkowanym przez setki fortepianów w warszawskich i krakowskich kamienicach na łamach prasy.

Podręczniki do gry na fortepianie ujawniają, jak wiele osób miało styczność z fortepianem w życiu codziennym polskich miast, dając lepszy wgląd w obszar zagadnień związanych z kulturą ówczesnych salonów. A zatem - szkoły gry można z powodzeniem wykorzystywać w procesie analizowania daleko większej ilości zjawisk na polu muzyki niż te związane bezpośrednio z techniką pianistyczną.

\section{BIBLIOGRAFIA}

Bourdieu, Pierre. Dystynkcja: spoteczna krytyka wtadzy sądzenia. Warszawa: Wydawnictwo Naukowe Scholar, 2005.

Bruliński, Michał. „Szafa - żyrafa - radioodbiornik: o fenomenie fortepianu w kulturze polskiej przed powstaniem listopadowym”. Praca magisterska, Uniwersytet Warszawski, 2016.

Chanan, Michael. Musica Practica. The Social Practice of Western Music from Gregorian Chant to Posmodernism. London: Verso, 1994.

Chmara-Żaczkiewicz, Barbara. Václav Vilém Würfel w Warszawie i w Wiedniu. Fakty i hipotezy. Warszawa: NIFC, 2017.

Chomiński, Józef, red. Stownik muzyków polskich. T. I-2. Warszawa: PWM, I964.

Dobrzyński, Bronisław. Ignacy Dobrzyński w zakresie dziatalności dążacej do postępu w muzyce we wspótczesnej jemu epoce. Warszawa: Lokomobila, 2007.

Dobrzyński, Ignacy Feliks. Szkota na fortepian poświęcona Rodakom. Warszawa: G. Sennewald, I842.

Dziadek, Magdalena. Od Szkoty Dramatycznej do Uniwersytetu. Dzieje wyższej uczelni muzycznej $w$ Warszawie I8Io-20I0. Warszawa: Wydawnictwo UMFC, 2011.

Goldberg, Halina. O muzyce w Warszawie Chopina. Warszawa: NIFC, 2016.

Gołębiowski, Łukasz. Gry i zabawy różnych stanów w kraju catym, lub niektórych tylko prowincjach. Warszawa: nakładem autora, I83I.

Green, Lucy. Music, Gender, Education. Cambridge: Cambridge University Press, 1997.

Harley, Hanna. „Pierwsze najpopularniejsze polskie szkoły na fortepian”. Ruch Muzyczny 9, nr 8 (1965): 8-9.

Hildebrant, Dietrich. Pianoforte: A Social History of the Piano. London: George Braziller Inc., I989. 
Kallberg, Jeffrey. Granice poznania Chopina. Warszawa: NIFC, 2013.

Kleczyński, Jan. „O konserwatoriach muzycznych”. Echo Muzyczne, Teatralne i Artystyczne I, nr 94 (I885): 284-285.

Kozłowski, Ignacy Platon. Szkoła teoretyczna i praktyczna na fortepiano, prowadzaca stopniami od pierwszych początków do najwyższych trudności. Moskwa: [bez wyd.], I832.

Kurpiński, Karol. Wyktad systematyczny zasad muzyki na klawikord. Warszawa: F. Klukowski, I8I8.

Loesser, Arthur. Men, Women and the Pianos: A Social History. New York: Dover Publications, 2011.

Mazepa, Leszek. Šlâh do Muzičnoï Akademï u L'vovi: u dvoh tomah. T. I, Vid dobi mis'kih muzikantiv do Konservatorï. Lviv: Vidavnictvo „Spolom”, 2003.

Mazepa, Leszek. „Szkolnictwo muzyczne Lwowa w okresie austriackim (I772-1918)”. Musica Galiciana I (1997): 8I-IO2.

Nowacki, Kazimierz. „Listy Franciszka Mireckiego”. Rocznik Krakowski 40 (1970): 68-72.

Nowakowski, Józef. Szkoła na fortepian podtug celniejszych autorów z dodatkiem ćwiczeń wtasnego uktadu. Warszawa: Rudolf Friedlein, I840.

Nowiński, Jan. Nowa szkota na fortepian obejmująca zasady muzyki, która wraz z uwagami tyczącymi sie gry fortepianowej, przestrogami dla początkujących nauczycieli i rodziców $i$ dla dopetnienia wtasnej ciekawszych nauki z celniejszych teoretyków zebrat i utożyt $w$ trzech cześciach. Kraków: D.E. Friedlein, ok. I839.

Ogiński, Michał Kleofas. Listy o muzyce, red. Tadeusz Strumiłło. Kraków: PWM, 1956.

Osiak, Elżbieta. „Polskie szkoły i podręczniki gry fortepianowej I800-I9I4”. Praca magisterska, Uniwersytet Warszawski, I994.

Parakilas, James, Piano Roles. The Hundred Years of Life with the Pianos. New Haven: Yale University Press, 2002.

Piekarski, Michał. „Ks. Wacław Sierakowski - propagator wiedzy o muzyce i organizator szkolnictwa muzycznego w okresie działalności Komisji Edukacji Narodowej”. Biuletyn Historii Wychowania 34 (2016): 85-99.

Poniatowska, Irena. Muzyka fortepianowa i pianistyka w wieku XIX: aspekty artystyczne i spoteczne. Warszawa: Oficyna Wydawnicza „Rewasz”, I991

Prokopowicz, Maria. „Z działalności księgarzy i wydawców muzycznych w latach I800-I83I”. W: Szkice o kulturze muzycznej XIX w., red. Zofia Chechlińska. T. I, 33-50. Warszawa: PWN, I97I.

Przybylski, Tadeusz. $Z$ dziejów nauczania muzyki w Krakowie od średniowiecza do czasów wspótczesnych. Kraków: Musica Iagellonica, I994.

Reiss, Józef, red. Almanach muzycznego Krakowa 1780-19I4. T. I-2. Kraków: Towarzystwo Miłośników Historii i Zabytków Krakowa, 1939.

Rottermund, Krzysztof. Budownictwo instrumentów muzycznych na terenie Wielkopolski w XIX i I. potowie XX wieku. Poznań: PTPN, 2002.

Rutkowska, Alicja. Dziatalność pedagogiczna Instytutu Muzycznego Warszawskiego (I860-19I7). Warszawa: PWSM, I960

Rutkowska, Alicja. „Nauczanie muzyki w Warszawie w II połowie XIX wieku”. W: Kultura muzyczna Warszawy II potowy XIX wieku, red. Andrzej Spóz, 34-4I. Warszawa: PWN, I980.

Rutkowska, Alicja. Rola spoteczna Instytutu Muzycznego Warszawskiego i znaczenie jego dziatalności dla polskiej kultury muzycznej. Warszawa: Akademia Muzyczna im. Fryderyka Chopina, 1980. 
Serbeńska, Zofia. „Warszawskie szkolnictwo muzyczne XIX wieku”. Praca magisterska, Uniwersytet Warszawski, I954.

Sikorski, Józef. Doręcznik muzyczny. Treściwe przedstawienie muzyki dzisiejszej, ze szczególnym baczeniem na miejscowe potrzeby, przyktadami w nutach do objaśnienia niektórych szczegótów niezbędnymi oraz stownikiem muzycznym. Warszawa: Drukarnia S. Orgelbranda, I852. Sikorski, Józef. „Jakim sposobem można się u nas kształcić w muzyce?”. Ruch Muzyczny I, nr 42 (I858): 332-333.

Sokulski, Antoni. „List o szkole muzycznej w Krakowie”. Czas 2, nr 4I (I849): I.

Sowiński, Albert, red. Stownik muzyków polskich dawnych i nowoczesnych. Paryż: Drukarnia E. Martinet, I874.

Stępniewska, Danuta, Barbara Walczyna, red. Kufer Kasyldy czyli wspomnienia z lat dziewczecych. Warszawa: Nasza Księgarnia, I974.

Wąsacz-Krztoń, Jolanta. Ludzie i muzyka w Krakowie w I potowie XIX wieku. Rzeszów: Wydawnictwo Uniwersytetu Rzeszowskiego, 2009.

Weber, Max. „Racjonalne i socjologiczne podstawy muzyki”, przekł. Marta Bucholc. Stan Rzeczy I (2013): II-26.

Vogel, Beniamin. Fortepian polski. Budownictwo fortepianów na ziemiach polskich od pot. XVIII w. do II wojny światowej. Warszawa: Sutkowski Edition, I995.

Vogel, Beniamin. Instrumenty muzyczne w kulturze Królestwa Polskiego. Przemyst muzyczny w latach I8I5-19I4. Kraków: PWM, I980.

\section{SELECTED POLISH HANDBOOKS OF PIANO PLAYING FROM THE FIRST HALF OF THE NINETEENTH CENTURY IN THE CONTEXT OF THE SOCIAL HISTORY OF MUSIC}

In this article, I analyse the possibility of using Polish handbooks and schools of piano playing as sources for research into the social history of that instrument, in the strict and the broad sense. The first part of the article consists of a synthesising survey of the rather scant subject literature and an outline of the role of the piano in nineteenth-century Polish culture. I then briefly describe the system of piano teaching in Polish lands during the early decades of the nineteenth century (under the Partitions), which was based on three main pillars: institutional education, private lessons (metra) and handbooks of piano playing.

This is followed by an interdisciplinary analysis of selected Polish piano schools from the first half of the nineteenth century (Karol Kurpiński's Wyktad systematyczny zasad muzyki na klawikord [A systematic presentation of the principles of music for the clavichord], I8I8; Ignacy Platon Kozłowski's Szkota teoretyczna i praktyczna na fortepiano [A school of theory and practice for the pianoforte], I832; Jan Nowiński's Nowa szkota na fortepian [A new school for the piano], I839; Józef Nowakowski's Szkota na fortepian podtug celniejszych autorów [A school for the piano after the leading authors]), I840; Ignacy Feliks Dobrzyński’s Szkota na fortepian poświęcona Rodakom [A school for the piano dedicated to my compatriots], I842). I focus mainly on the narrative sections of the source materials. This survey made it possible for me to reconstruct the model structure of a piano handbook during the period under discussion. I study this information in the context of our current knowledge about the phenomenon of the piano, as represented in the press, correspondence, memoirs and fiction. I conclude 
my paper with a few observations concerning the social aspects of the piano in Polish lands during the first half of the nineteenth century and the evolution of those aspects, as well as models of musical education and the external and internal fluctuations of Polish pianism at that time.

Translated by Tomasz Zymer

Słowa kluczowe / keywords: podręczniki do gry na fortepianie / handbooks of piano playing, fortepian / piano, pianistyka / pianism, edukacja muzyczna / musical education, Karol Kurpiński, Ignacy Platon Kozłowski, Franciszek Mirecki, Antoni Sokulski, Jan Nowiński, Ignacy Feliks Dobrzyński, Józef Nowakowski, Józef Sikorski, Fryderyk Chopin, Józef Elsner

Michał Bruliński ukończył studia pianistyczne w klasie Ewy Pobłockiej na UMFC, historię oraz Kolegium Artes Liberales na UW, gdzie obecnie pracuje nad doktoratem w ramach Środowiskowych Transdyscyplinarnych Studiów Doktoranckich. Zajmuje się badaniem społecznej historii muzyki oraz historii kultury XIX i XX wieku. Jego teksty publikowane były m.in. przez Instytut Pamięci Narodowej, kwartalniki Kronos i Opcje, Ruch Muzyczny oraz przez Wydawnictwa UMFC. Za osiągnięcia naukowe i artystyczne nagradzany był stypendiami m.in. MKiDN, Rektora UW, Rektora UMFC oraz Burmistrza Miasta Milanówka. Od 2012 r. związany jest z Narodowym Instytutem Fryderyka Chopina. Od 2017 r. pracuje jako wykładowca na UMFC, prowadzi także zajęcia na Wydziale „Artes Liberales” oraz na Wydziale Historycznym UW. m.brulinski@al.uw.edu.pl

\section{Film o kwartalniku MUZYKA}

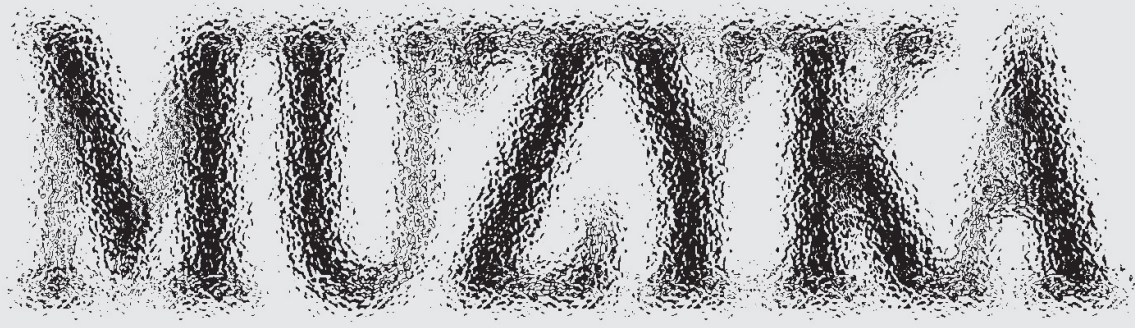

